\title{
Why meaning-making matters: the case of the UK Government's COVID-19 response
}

\author{
Marcus Morgan ${ }^{1}$ \\ Published online: 15 October 2020 \\ (c) Springer Nature Limited 2020
}

\begin{abstract}
Through analysis of the UK government's management of the COVID-19 outbreak, this paper offers an empirical demonstration of the principle of culture's relative autonomy. It does so by showing how the outcome of meaning-making struggles had impacts on political legitimacy, public behaviour, and control over the spread of the virus. Ultimately, these impacts contributed to the avoidable deaths of tens of thousands of UK citizens. Dividing the crisis into phases within a secular ritual passage or 'social drama', it shows how each phase was defined by struggles between the government and other actors to code the unfolding events in an appropriate moral way, to cast actors in their proper roles, and to plot them together in a storied fashion under a suitable narrative genre. Taken together, these processes constituted a conflictual effort to define the meaning of what was occurring. The paper also offers more specific contributions to cultural sociology by showing why social performance theory needs to consider the effects of casting non-human actors in social dramas, how metaphor forms a powerful tool of political action through simplifying and shaping complex realities, and how casting can shift responsibility and redefine the meaning of emotionally charged events such as human death.
\end{abstract}

Keywords Coronavirus · Social drama $\cdot$ Narrative genre $\cdot$ Casting $\cdot$ Performance Meaning-making

\section{Introduction}

'Any important disease, whose physical etiology is not understood, and for which treatment is ineffectual, tends to be awash in significance' (Sontag 1978).

This paper demonstrates the real-life impacts of meaning work through an analysis of the sense-making struggles that took place around the UK government's

Marcus Morgan

marcus.morgan@bristol.ac.uk

1 School of Sociology, Politics and International Studies, University of Bristol, 11 Priory Road,

Clifton, Bristol BS81TU, UK 
response to the COVID-19 crisis. It argues that events fell roughly into three periods, understood as a succession of phases in a secular ritual passage or 'social drama' (Turner 1969, 1980; Fig. 1). These phases were defined by changes in the moral coding of events, modifications in the casting of actors involved, and alterations in the dominant narrative genre within which events were to be understood. This dynamic chronology therefore constituted a conflictual effort to define the meaning of what was going on. It will show how the outcome of these struggles over meaning-making ultimately impacted not only government legitimacy but also the avoidable deaths of tens of thousands of UK citizens.

During the first period (early January to mid-March), the viral threat was identified, but little was done to counter it. Events were narrated in a low mimetic mode that cast the virus as an object of routine and mundane political management. Banal measures, such as handwashing, were recommended to control the disease, and the Prime Minister instructed the public that 'they should, as far as possible, go about business as usual' (quoted in Calvert et al. 2020, May 24). British social structure remained intact, and the virus was presented as one amongst a number of problems to be dealt with. This response allowed the virus to spread unobstructed throughout the population. As this period progressed, however, and especially from early March onwards, polarisation grew, government legitimacy declined, narrative inflation took place, and the viral antagonist increasingly became cast as a mortal enemy. Pressure - much of it from outside government-eventually succeeded in forcing a ritual breach to occur, and a crisis to be declared in order to deal with the deadly 'invader'.

Though changes in the government's conception of the virus were underway from early to mid-March, significant practical measures of redressive action only arrived on 23rd March when lockdown came into effect and the UK properly entered its second, liminal period. During this period, routine social life was suspended, antistructure became the norm, and significant measures to control the spread of the disease finally, and belatedly, arrived. Government legitimacy rose during this period and focussed ritual expressions of communitas occurred in which social solidarity was expressed with those working on the 'frontline' in fighting the virus. As we shall see, these secular rituals did not, however, magically resolve various significant social cleavages within British society, and in many ways ended up dramatising these latent divides in more vivid light. This second period was narrated in the high mimetic mode of tragedy that drew upon the highly polarised, and occasionally even apocalyptic, language of warfare. One important episode in this period-Boris Johnson's illness - even reached into the lofty genre of romance and legend, in which the PM-as-hero was cast as possessing preternatural powers of agency in his personal capacity to fight off the virus. The government also attempted to recast, or interpellate, a range of other actors from both within and beyond the government during this middle period, with varying degrees of success. Attempts, for instance, were made at redistributing responsibility by recasting senior medical and scientific advisors as ultimately accountable for the government's policy decisions, and the general public as liable for following them. NHS staff and other frontline workers were recast as 'heroes' and eulogised in that role in ways that profoundly reframed the meaning of their mounting deaths. Attempts at co-opting external actors to play along with one's intended direction are, however, inevitably unpredictable and the paper will explore 


\begin{tabular}{|c|c|c|c|}
\hline 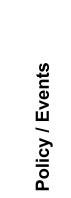 & 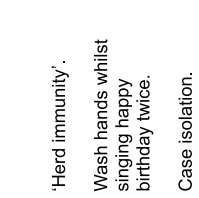 & 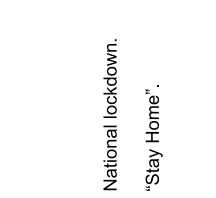 & 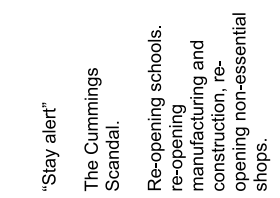 \\
\hline 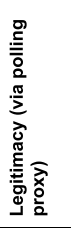 & 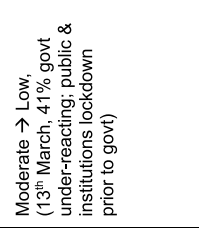 & 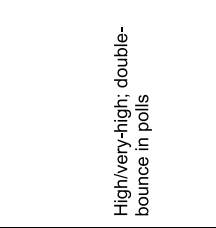 & 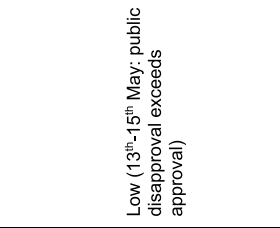 \\
\hline 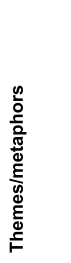 & 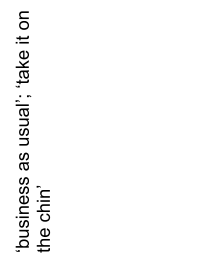 & 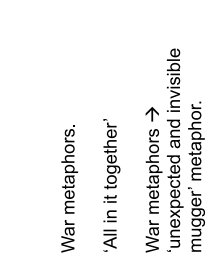 & 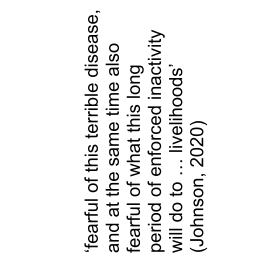 \\
\hline 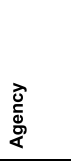 & 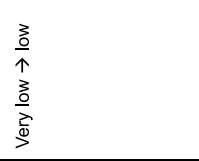 & 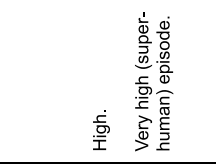 & 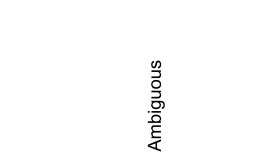 \\
\hline 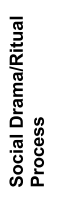 & 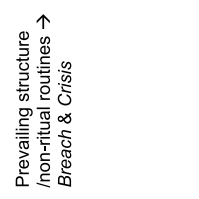 & 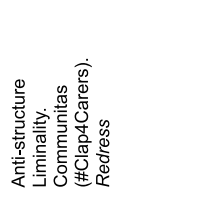 & 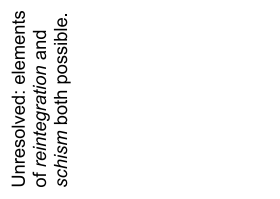 \\
\hline 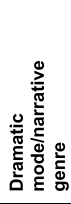 & 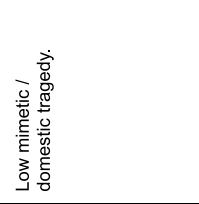 & 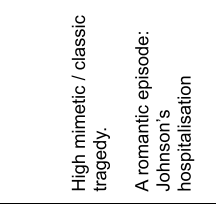 & 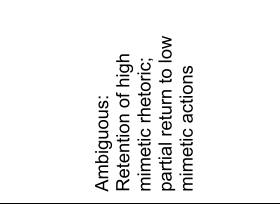 \\
\hline 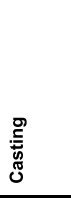 & 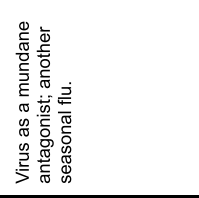 & 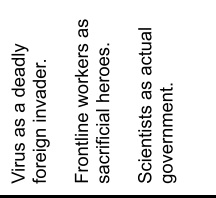 & 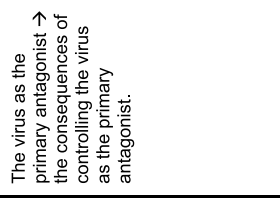 \\
\hline 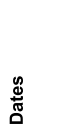 & 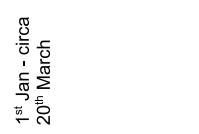 & 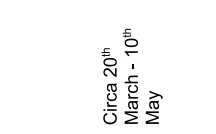 & 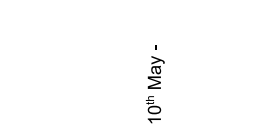 \\
\hline
\end{tabular}

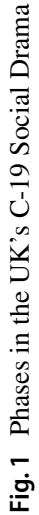


the failures of these casting efforts, showing how at various junctures uninvited actors inconveniently pushed their way onto the public stage in ways that threatened to undercut the government's intended drama.

The third and final ritual phase was announced on 10th May, came into effect from the beginning of June, and is ongoing. Turner makes clear that 'social dramas, especially under conditions of major social change, might not complete [their] course' (1988, p. 35). This period has so far been characterised by ambiguity and incompleteness. Attempts at narrative deflation have been uneasily combined with the inflated moral coding that prevailed during the previous phase, and strong elements of liminality have also remained. It will be shown how the government's ability to successfully narrativize this period has been thrown into jeopardy by contradictions in government actors' own public performances, typified by revelations of a major political scandal involving the PM's top advisor. The effect of these failures is evidenced by a stark decline in government legitimacy during this period, and widespread confusion over government rules and guidance around COVID-19.

Since COVID-19 has spread throughout the globe, and different nation-states have responded in different ways, with differing health outcomes, the pandemic therefore presents social science with a large- $\mathrm{N}$ dataset that can be used for comparative purposes. This means that a large number of different cases can be observed empirically, without the need to imagine speculative counterfactuals. Placed within this international comparative context, it is hard to escape the conclusion that whichever way you measure it, and especially in light of the UK's relatively advanced warning of the virus, the UK's response has been woeful, resulting in tens of thousands of avoidable deaths (Aljayyoussi and Cross 2020). A primary contention of this paper is that this abysmal public health outcome was in part an effect of the efforts to fix meaning around the virus by the politicians who directed the response. Different constructions of the virus's meaning by powerful political players became quite literally a matter of life and death for many.

The paper therefore wishes to illustrate the real-life (and more to the point, realdeath) causal impacts of culture, identifying, with some degree of specificity, 'just how culture makes a difference' (Alexander and Smith 2003, p. 14). It intends to show how cultural analysis is not condemned to producing vague descriptions of social life that skirt around the edges of specifying explanatory mechanisms. Despite what some of its critics may claim, cultural analysis need not remain stuck on some destabilising merry-go-round of ever-undercutting hermeneutic circles but is instead able to come good on Dilthey's (1972 [1900], 2002) original goals for interpretive enquiry. These goals never intended to banish explanation from the human sciences, but instead aimed to reconstruct meanings in such a way as to build explanations appropriate to the human sciences. In order to effectively render meaningful 'forms of life', narrative reconstructions ought to rely upon, and take seriously, the categories used by social participants themselves (Tsilipakos 2020; Winch 1958, pp. 40-65), though this does not mean they need not remain inside such categories in offering their explanations. The case of COVID-19 reveals how struggles over sense-making - such as fixing the genre under which events are understood, or the effective casting of human and non-human actors-can affect whether or not populations find themselves exposed to mortal risk. Culture, in other words, is revealed 
in this paper to act as a mechanism through which the sovereign power to 'expose to death' - what Mbembe (2003) has called necropolitics - is able to function.

Methodologically, these explanatory pathways are traced through an historical reconstruction of dominant meanings that were projected-with variable degrees of success and contention-from centres of power. The paper shows how these meanings shaped interpretation, behaviour, policy, public legitimacy, and ultimately the spread of infection and death rates. To do this, it draws its empirical data from transcripts of the government's daily press conferences, recorded media appearances of politicians and scientists, press briefings, investigative TV, newspaper journalism and media reports that provided the 'first rough draft of history', social media posts, open letters, and newspaper front-page headlines. The information sources are limited, and a full picture would require declassification of internal Downing Street communications that ought to become the focus of any future public enquiry. Nevertheless, to unpick the public messaging itself, and the responses it received, no such data are required. It will also use political polls as imperfect proxies for measuring government legitimacy at various moments. Another limitation in the data has been the difficulty of accurately tracking the variation in infection rates at different periods, which is itself a consequence of the lack of a systematic testing system. Rather than a comprehensive overview of events, it focuses in on shifts in messaging and symbolic action, moments where sudden change can be detected.

It will tell two stories: one of a national public health catastrophe, in which over 57,600 deaths have so far been registered in the UK where C19 was mentioned on the death certificate; another of a public relations exercise, in which casting, narrative, and performance were deployed in an effort to shield the government from responsibility, with the frequent effect of exacerbating the crisis. It will therefore focus on efforts to contain two types of contagion: one viral, the other symbolic, and examine the dangers of treating public policy around matters of life and death as a matter of political communications; of managing a public health crisis as though it were a public relations one.

Given the openness and complexity of social systems, unlike stage dramas, the genesis and termination of social dramas, as well as the identification of the relevant parties involved, is a matter to be determined, and justified, by social analysts themselves. The events described below unfolded within other, more panoramic social dramas, and themselves contained many smaller, more focussed social dramas. In presenting my own narrative, I am conscious that I am both adding another layer to the storytelling and smuggling in my own account of the appropriate analytic forms and categories through which to understand these extraordinary events. A physical virus, and the substantive suffering involved in the death it causes, might seem to somehow spontaneously contain its own interpretation. This paper intends to demonstrate how nothing could be further from the truth. As we shall see, the meaning of the virus, the performance roles of those who acted to control it, and the significance of the death it caused, were all subject to highly contested meaning work. Certain conventional understandings of a pandemic's meaning, derived from historical and popular artistic representations (Wald 2008), no doubt influenced the interpretation of $\mathrm{C} 19$, as did even more generalised and generic narrative forms. Nevertheless, the crisis also offers a stark example of an 'unsettled time' (Swidler 1986), in which 
the field of meaning was thrown open for interpretation and struggles to define its symbolic significance ensued.

\section{Casting}

The control that directors exert over conventional stage plays allows them to construct a 'relatively contrived illusion' involving 'the maintenance of a single definition of the situation' (Goffman 1959, p. 246). In contrast, real-life social dramas are obliged to work with highly contingent and often radically uncontrollable actors and conditions. Rarely do preformed, coherent, and consensually coordinated 'performance teams' exist at the outset of a social drama (Goffman 1959, p. 104; Morgan and Baert 2015, pp. 36-37), and this is one feature that renders social dramas more akin to improvisational theatre than the conventional stage play that the dramaturgical tradition has typically used as its referent. As all experienced improv actors know, audience participation-which might be thought of as an implicit casting of the audience into an intended projection of meaning-always operates within a 'horizon of risk' (White 2013, pp. 73-94). This risk derives from the fact that audience members do not always play ball. Stubborn inductees have their own ways of answering the question of 'what is it that's going on here?' (Goffman 1974, p. 8 ), which rarely align perfectly with the intentions of those directing the show. To increase the likelihood of conformity, one influential manual suggests that audience 'volunteers must be treated with love and generosity' (Johnstone 1981, p. 14), a matter that will be shown to be important later on in this paper.

Other clues as to how external actors can be successfully enlisted into a particular drama come from the radical tradition of social theory. Althusser famously explored how states, and their varied institutions, effectively maintain social control through ideological processes that help reproduce social subjects as beings who tend to naturally identify themselves with those institutions. Those experiencing the effects of ideology, whether capitalist or otherwise (Althusser 2014, pp. 227-228), come to see themselves as spontaneously at one with certain categories and ways of thinking and acting. When this occurs, such subjects have, in his parlance, become 'interpellated as subjects' (ibid., pp. 267). 'Interpellation' refers here to the process of being hailed and-identifying yourself as the subject who is being addressed-turning around to acknowledge that the call was indeed meant for you (ibid., p. 164, p. 191). Althusser's account rests upon an elevation of the theoretician of Ideologiekritik as capable of penetrating illusion in a context in which mere mortals are assigned no such powers. More importantly though, in spite of his favoured use of the term 'subject', once Althusser is done with her, this figure has very little of what we would conventionally identify as 'subjectivity' left. These problems, alongside various others, provoked a particularly vociferous critic of structural Marxism to dismiss interpellation as a 'grotesque notion' (Thompson 1978, p. 148). Nevertheless, even flawed concepts have their uses when adapted or applied in contexts other than those for which they were designed, and I intend to both adapt and resituated Althusser's concept here. 
I intend to adapt it by offering far greater agency to subjects in refusing to be interpellated in the roles assigned to them, ${ }^{1}$ and to resituate it by transplanting it into the wider field of social drama, where it comes to be seen as similar to the attempts at audience participation or 'casting' introduced above. This latter term is useful in allowing us to speak sensibly of how the virus itself was cast in a particular dramatic role at different periods within the drama, since a virus can hardly be said to be interpellated given its incapacity to subjectively recognise itself in its assigned role. Whereas most of the studies following the performance turn in cultural sociology, as well as Turner's own account, have assumed that the characters that populate social dramas are human agents, in these events, the virus itself became cast as an antagonist with varying powers of agency assigned to it at different phases in the drama. Recognising this, need not entail hyperbolic post-humanist claims concerning nonhuman 'actants' (Latour 1996, pp. 373-379; cf. Morgan 2016, pp. 38-42), but simply implies an acknowledgment that objects other than human beings serve functional roles in storytelling processes. However, whilst useful for capturing the ability of an actor to resist enrolment, and also for the capacity of non-human entities to become enlisted in a story, the relatively neutral term 'casting' proves inadequate for capturing the power relations involved in many of the ways that actors are often dragooned into their roles. The power of the government's intended casting of the scientists who advised them, for instance, was shored up by the status of many of those scientists as employees of that same government. Such power relations did not, however, automatically determine casting outcomes, and as well as identifying conformity, the paper will also review those moments in which scientists rebelled against their assigned roles and blew the whistle on the government's mishandling of the crisis.

\section{Narrative and Social Drama}

Role casting is only effective to the extent that actors conform to a broader storyline and a more focussed script, which are by definition extended through time. The same is true of the moral coding of objects and events as good or evil: coding's efficacy, which may be thought of as the organisation of events and objects in conceptual space, is only realised once a diachronic movement is introduced to plot these objects and events in evolving narrative time (Alexander 2006, pp. 60-62). Getting at this dynamism, Ricoeur describes a story as 'a sequence of actions and experiences of a certain number of characters, whether real or imaginary ... represented in situations which change ... [and to] which they react' (Ricoeur 2016, p. 239).

English Studies scholars have looked at the way in which popular stories of communicable disease are shared across different outbreaks and circulate within populations very much like diseases themselves do. It has been shown how these stories can then go on to influence responses to outbreaks, both by authorities and by those affected by the disease (Wald 2008). Sociologists have examined the role of personal narratives in making sense of the lived experience of pandemics (e.g. Davis

1 This also assigns greater responsibility for those cast in particular roles to resist their casting.

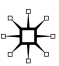


and Lohm 2020), and historians have also applied dramaturgical models to show how epidemics are constructed through narratives that share particular motifs and metaphors (e.g. Rosenberg 1989, 1992). Tracking similar lines to Van Gennep's and Turner's tripartite account of the ritual passage explored here, Rosenberg, for instance, identifies how epidemics 'follow a plot line of increasing and revelatory tension, move to a crisis of individual and collective character, then drift toward closure' (1989, p. 2).

Salmon $(2017$, p. 6) is correct to point out that narrative has often functioned 'as a technology of communications, control, and power', even if he incorrectly characterises this development as a relatively recent phenomenon. His account also tends to neglect that what Plummer (2019) calls 'narrative power' can be used to challenge as well as legitimate authority (e.g. Polletta 2006; Alexander 2011; Olsen 2014). Whilst dominant powers tend to have greater access to, and control over, 'means of symbolic production', alternative stories can and do get voiced in the public sphere, and authorities are often forced to adapt their own stories in response (Davis 2002).

Whilst the COVID-19 outbreak is ripe for sociological analysis of the various speech genres deployed at different phases of its management (Bakhtin 1986), the aspect of genre theory relied upon most here will instead be that concerned with narrative genres (Barthes 1977), both in their ability to account for a mechanism of the exercise of power, and their affording the possibility of a 'structural hermeneutics', which enables 'the construction of models that can be applied across cases and contexts but at the same time provid[ing] a tool for interrogating particularities' (Alexander and Smith 2003, pp. 25-26). Adapting Northrop Frye's (1957) classic Aristotelian statement on literary criticism, Smith (2005) has shown how locating one's narrative in the appropriate archetypal genre can help politicians justify exceptional policy and mobilise dramatic forms of social action. This is because narrative genre helps organise both the cognitive and emotional response to events. For social narratives to be effective, politicians must not only plot them in an appropriate way, but, citizen-audiences must of course be willing to read and experience them in that same way. Plotting events in one genre rather than another expands or contracts the possibilities for action that we might expect from both protagonists and antagonists, encouraging certain beliefs about their character whilst discouraging others.

The focus here will be on what Turner calls the 'star groupers' of the public sphere, those 'main protagonists ... who develop to an art the rhetoric of persuasion, who know how and when to apply the pressure and force, and who are most sensitive to factors of legitimacy' (1980, p. 152). This group therefore excludes individuals who circulate stories in private discussions during pandemics (Davis and Lohm 2020), the content of which may be used to index the efficacy of the star groupers' own interventions, but who nevertheless fail to define a situation in any significant way for broader social groups. Politicians form the most prominent element of this star group and though their interventions are far from infallible, and though their public utterances may be characteristically carefree with it comes to meeting truth conditions, they are typically hyper-aware of the felicity conditions that need 
to be met for their performative acts and utterances to come off effectively in front of enfranchised public audiences. Other contributors to this symbolic public sphere included journalists, scientists, doctors, nurses, and organised or disorganised members of the public who in open letters, tweets, television appearances, and op-eds tried to impose their own narrativization of the events and attempted to cast various actors, including the virus itself, in ways that often diverged from the government's own efforts at fixing meaning.

Smith's (2005) focus is on the way that governments drum up support for the extreme act of war, with all its attendant human sacrifice. Given that war is typically considered in realpolitik terms of the clash of instrumental powers, material competition, or violence, it provides an excellent test case for a cultural sociological approach to explanation, since the proposed hypothesis is considered improbable within conventional social science (Popper 1963, p. 77). Theories of 'perpetual war' notwithstanding (Keen 2006), taken as a discrete event, war is an extraordinary occurrence that in most contemporary societies requires justificatory work for governments to avoid becoming enveloped in a 'legitimation crisis' (Habermas 1988). To motivate a population to engage in exceptional acts such as war, politicians must plot real-life events in a convincing sequence that is usually characterised by a highly charged apocalyptic struggle between protagonists, coded as absolutely good, and antagonists, coded as absolutely evil. The consequence of this struggle must be presented as the fate of a society's highest ideals. Whether or not base and material motivations-imperial expansion, resource extraction, military-industrial complexes, etc.- - are in fact driving states to wage war, in national democratic contexts, and international contexts governed by conventions and treaties, war narratives must be pitched in such a way that evil forces come to be seen as threatening what a society holds most dear. In such scenarios, it must come to be seen that without war liberty or justice, for instance, will be banished; with war they will be protected or extended. Stories must be told in such a way that blood sacrifice is considered an acceptable price for a society to pay in order to protect its most treasured ideals.

Drawing directly upon Aristotle (1996), Frye (1957) describes five 'fictional modes' on the basis of the hero's role vis-a-vis the audience.

(1) The dramatic mode most removed from the mundane is the mythic, in which the hero 'is superior in kind both to other men and to the environment of other men'. Such a hero therefore occupies the realm of the divine.

(2) Slightly closer to earth, in the romantic mode, the hero is 'superior in degree to other men and to his environment' (ibid., p. 33). Such a hero therefore 'moves in a world in which the ordinary laws of nature are slightly suspended: prodigies of courage and endurance, unnatural to us, are natural to him' (ibid.). The romantic hero is the protagonist we find not in myth, but in legend.

(3) Touching down to earth, the hero of the high mimetic mode is 'superior in degree to other men but not to his natural environment' (ibid., pp. 33-34). Such a hero is therefore bound by the same mundane constraints as others but is more capable than most in his ability to bend and overcome them. Frye associates this mode with great leaders, and it is the hero we find in the genre of tragedy that preoccupies Aristotle's Poetics. In using this term 'mimetic', Aristotle draws upon Plato's notion of art as mimêsis, or imitation, of life. Aristotle stressed that in tragedy, there must 
be both a closeness and a distance between life and its imitation in order for art to achieve a 'purification of ... emotions' (katharsis), especially those of 'pity and fear', and it is from this emotional purging that the audience's pleasure in dramatic tragedy was derived (Aristotle 1996, pp. 10-12). The closeness to real life allows the audience to identify with, and be moved by the characters, whilst the distance from real life allows them to rest assured that it is not them who are undergoing ill. Ricoeur introduces another function of art's mimetic distance from reality in his observation that storytelling 'refers to reality not in order to copy it' in any direct sense, 'but in order to prescribe a new reading' (Ricoeur 2016, p. 255). In this sense, a good tragedy is never entirely realist, but always involves a certain stylisation. It is 'a kind of metaphor of reality', that imitates reality 'in accordance with its magnified essential features' (ibid.).

(4) Firmly rooted in the world of the everyday is the low mimetic hero. Such a protagonist is 'superior neither to other men nor to his environment'. In realist fiction in the low mimetic mode, we are moved by such a hero precisely because they are one of us; in low mimetic comedy, we are amused by them because we recognise their flaws in the worst aspects of ourselves.

(5) Finally, we find a hero who is 'inferior in power or intelligence to ourselves' (Frye 1957, p. 34) in the ironic fictional mode. Here, the protagonist-hardly any longer a hero, and certainly not in the modern sense of that term-is a frustrated, pathetic, or absurd figure, and readers of such literature can rest assured of their superiority in being capable and conscious in ways that this protagonist is not.

As we move down this hierarchy of narrative modes, it is important to point out that the powers of the hero to act on the world around them-to manage or resolve a crisis, for instance-are progressively diminished.

Smith (2005, pp. 21-22) adds three additional dimensions to Frye's generic schema. First, as narrativization moves away from the ironic and towards the mythic mode (a process he calls 'narrative inflation'), heroes' motivations become less base, and more ideal. Second, it is not only the protagonist's perceived powers to act that are expanded, but also those of the antagonist. As acts of good and evil become more momentous and dramatic, moral polarisation between the hero and the enemy is therefore also increased, and the antagonistic characters take on an increasingly emblematic appearance. Finally, as we move up the narrative hierarchy, the 'issues' at stake also grow in significance and gravity, 'the future of kingdoms and even the world may be at stake and transcendental themes relating to the need for salvation and redemption become increasingly significant'.

A key insight of cultural pragmatics is that culture structures both enable and constrain action, which is one way of establishing culture's relative autonomy. Whilst agency is key, e.g. in attaching particular real-life events to generic narrative forms, at the same time, culture structures inhibit agency, blocking various possibilities as they open up others. I will try to show how at different points in the UK's C19 crisis, culture workers exerted agency in attaching events to different generic narratives, which both facilitated various forms of action, but simultaneously foreclosed others. Once, for instance, the antagonist-virus was successfully narrativized in high mimetic terms as an 'unprecedented', even 'devilish', threat to society, this 
opened the door to interventionist state action, at the same time as it closed the door to inaction in the face of a morally inflated threat.

Where Smith (2005, pp. 232-233, n4) chooses to neglect the significance Frye places on the use of metaphor, this article will address metaphor directly, showing how the dynamics of the real wars that Smith analyses offered important narratological functions when used as symbolic metaphors for fighting disease, for as Bruner (1990, pp. 59-60) points out, 'narrative is not just plot structure or dramatism ... "historicity" or diachronicity. It is also a way of using language [that] relies upon the power of tropes - upon metaphor, metonymy, synecdoche, implicature, and the rest'.

It will also try to show how literary theories of narrative genre can complement, and be interwoven with, anthropological theories of ritual process and social drama, the utility of which has already been demonstrated elsewhere (e.g. Jacobs 1996). Social drama itself is, after all, a kind of narrative, a story composed of a 'sequence of social interactions of a conflictive, competitive, or agonistic type' (Turner 1988, p. 33). Ritual, and the contemporary pseudo-rituals we find in social dramas, are also processes that when successful are, like good tragedies, able to 'achieve genuine cathartic effects' (Turner 1974, p. 56). Elsewhere, Turner (1980, p. 153) makes clear that

'there is an interdependent, perhaps dialectic, relationship between social dramas and genres of cultural performance in perhaps all societies. Life, after all, is as much an imitation of art as the reverse ... genres ... serve as paradigms which inform the action of important political leaders ... giving them style, direction, and sometimes compelling them subliminally to follow in major public crises a certain course of action, thus emplotting their lives'.

Turner's (1969) account of the ritual process drew upon van Gennep's (2004) model of rites of passage and his own ethnographies of traditional, tightly integrated and non-differentiated societies such as that which he found amongst the Ndembu of Zambia. However, he later adapted his concepts to fit complex, non-traditional societies too. Modernising Turner's approach a step further, cultural pragmatics has emphasised the difficulties - though not impossibilities — of achieving the kinds of ritualistic 'fusion' that were common in more simple societies, due to the highly contingent, reflexive, and 'de-fused' nature of the modern world (Alexander 2004; Morgan 2020).

This argument mirrors others that we find in literary theory. Whether or not one accepts the 'Cambridge thesis' concerning the origins of theatre in ritual (Cornford 1914; cf. Schechner 1988, pp. 1-6), Frye's description of the high mimetic mode of Greek tragedy emphasised its integrated unity of focus, in which the hero becomes the 'cynosure' of the audience (1957, p. 58), just like the totem forms the centre of attention for rites of worship in certain indigenous societies. Recall that in tragedy, mimesis works in such a way that the fictional hero is also cast as higher in powers than the mortals that he or she imitates in ordinary life, just as for Durkheim 'the images of totemic beings are more sacred than the beings themselves' (Durkheim 1995, p. 134). In this respect, unlike the low mimetic mode, which involves fictional forms that 'deal with an intensely individualized society' the 'centripetal gaze' of the higher mimetic modes seem to share something with ritual, for it 'seems to have 
something about it of the court gazing upon its sovereign, the court-room gazing upon the orator, or the audience gazing upon the actor' (Frye 1957, pp. 58-59). As we work up the narrative ladder to the realm of myth, we are quite explicitly dealing with the sacred realm of the gods.

Lukács's Theory of the Novel reveals something similar in its tracking the decline of both epic poetry and dramatic tragedy, which he tells us emerged from the 'integrated civilisation' of the Ancient Greek world (1971, pp. 29-39), and the rise of the novel, as a modern attempt to recapture some of this unity in a socially fragmented, and individually alienated, contemporary setting (ibid., pp. 56-93). The novel, for Lukács, was an expression of our striving for something more universal in the tensions it exhibits between the way the world is and our idealistic motivations to overcome reality's constraints. For cultural pragmatics, the pseudo-ritual process in contemporary societies is similarly strained between on the one hand, disenchanted conditions of de-fusion and differentiation, and on the other, a striving for re-enchantment, shared meanings, and collective solidarities. Under such conditions, culture can still bind social groups together, but it does not come about with such ease and spontaneity. Participation cannot be assumed, and the different 'elements of performance' need to be actively brought together and made to work in synchrony. Fusion therefore relies upon the artistic skill of actors and directors in successfully orchestrating social performance.

In what follows, this paper will describe efforts at such orchestration, and the ways in which such efforts were routinely undermined, both by the inartistic skills of their authors, and the refusal of actors to be interpellated. It will show how conceiving the handling of the UK's COVID-19 outbreak as progressing through the stages of a secular ritual process sheds light on how crises are triggered, how they are elevated to dramatic heights, and how they are lowered back down again.

\section{Phase I: COVID-19 Narrativized in the Low Mimetic mode}

This section will describe how the UK government ignored various alarming warnings that suggested the immediate necessity of initiating a social drama around the virus. Instead, throughout the first three months of the year, the government chose to narrativize the outbreak in 'low mimetic' terms which disallowed the possibility of an effective response being taken to control its spread and prepare the health service for the severe outbreak that was brewing. 'Low mimetic' narrativization barred recognition of the virus as a tragic threat, and therefore prohibited extraordinary action being taken to avert it. Ritual breach into an anti-structural state was, in other words, foreclosed, and the everyday routines and structures of British society remained intact, allowing the deadly virus to disperse throughout the population and eventually kill an extraordinary number of UK citizens in the weeks and months ahead. This section will describe how all this was enabled under the banner of 'herd immunity'. It will describe how such symbolic labels were connected to the narratives through which the public were being encouraged to understand the meaning of the virus and show how these culture structures did not only exist at the level of ideas but were also communicated in concrete acts of political performance. Finally, 
this section will show how these sense-making efforts from above proved ultimately ineffective in imposing their intended meanings, as public institutions and individuals took matters into their own hands, rebelled against the government's laissez faire approach and began taking their own prohibitive measures towards the viral threat. These actions 'from below' led to narrative inflation, paving the way for the belated casting of the virus as a tragic threat that was to define Phase II of the national drama.

January, 2020 began with China reporting its first death from the novel coronavirus in Wuhan, and concluded with the UK leaving the European Union. The latter event was marked by Prime Minister Johnson delivering a public address in which he declared that 'the dawn breaks and the curtain goes up on a new act in our great national drama'. Similarly to 1918 , when Woodrow Wilson was so distracted by WWI that he failed to recognise the emerging threat posed by the so-called 'Spanish flu', the UK government were later criticised for being too involved in their promise to deliver Brexit, and deal with other domestic issues such as severe winter flooding, to adequately acknowledge the far more momentous drama that was looming on the horizon. The day prior to Johnson's use of theatrical metaphor, the WHO had declared that COVID-19 constituted a Public Health Emergency of International Concern, advising governments of 'all countries' to take immediate action, readying themselves 'to contain any introduction of the virus and its spread through active surveillance, early detection, isolation and case management, contact tracing and prevention' (WHO 2020a, b).

The WHO's announcement, and many subsequent warnings, could have provoked the government into initiating a social drama around the virus much earlier, as occurred in many comparable nations. This would have involved acknowledging a 'breach' and coding the virus not merely in mundane technical terms, but in extraordinary moral terms, as a threat to cherished values, such as life and livelihood. Such coding could have spurred public legitimacy for the rapid declaration of a 'crisis' that would demand radical redressive measures. If this had occurred in good time, the deadly scale of the crisis might have been 'sealed off quickly within a limited area of social interaction' (Turner 1974, p. 38) as occurred in for instance, in New Zealand. Rather than conjecturing about counterfactuals though, this section will describe what in fact happened: how throughout January, February, and into early March, the UK government narrativized the COVID-19 outbreak in 'low mimetic' terms which prohibited a timely breach, prevented dire coding, and barred the possibility of consequential action being taken to avert it.

Smith talks about how '[c]risis situations involve a genre guess made from a few events and then ongoing efforts to check this as things develop' (Smith 2005, p. 31). In some ways, the periodic revisions that the UK government made in its generic narrativization of the developing COVID-19 situation are accurately described by this notion of a 'genre guess'. In other ways, however, the phrase does not quite fit. This is because politicians were not simply guessing at what genre most accurately fit the unfolding events, but instead-in a context in which other imperatives, such as economic and political motivations shaped decision-making-they were attempting to actively impose their chosen narrative, to which they hoped the reallife events themselves might be made to conform. Contagious disease has long been 
narrativized in the literature and film in apocalyptic terms, and in the Book of Revelation, Plague is indeed one of the Four Horseman of the Apocalypse. This would seem to suggest that if politicians were simply guessing what genre to place events under, conventionally, a deadly pandemic would scream out for narrativization in an apocalyptic, or at least a high mimetic, narrative mode. This was not, however, forthcoming, until a large degree of damage had already been done. Instead, the government decided upon low mimesis, a narrative mode that 'takes life exactly as it finds it' (Frye 1957, p. 41), and which whilst involving the resolution of some weak level of binary conflict lacks the dramatic potency of tragedy, let alone the apocalyptic contradictions of good and evil necessary for acts of war. Smith describes how the weak character polarisation of the low mimetic mode leads it to 'understand crises as fixable through prudence' $(2005$, p. 25$)$, and in this case, the virus was initially cast as a mundane hazard to be overcome by prosaic forms of individualised action, rather than the coordinated and enforced measures that were to be belatedly introduced in the second period.

The UK Health Secretary was first alerted to COVID-19 on 3rd January and on 21st January, Neil Ferguson provided a report to COBRA showing how the infectivity rate was certainly higher than seasonal flu and could be higher than the Spanish flu (Calvert et al. 2020, April 19). On 23rd January, the UK Department of Health's first Press Release on the new virus described its risk to the public as 'very low' (DHSC 2020). A different narrative genre had clearly taken hold amongst political leaders in China, who the next day placed Wuhan, which contains over 11 million inhabitants, into complete lockdown. Soon the whole of the surrounding Hubai province was placed under the same measures. If this event was registered at all in the UK's official communications, it might be detected in the modifier 'very' having been removed when the Chief Medical Officer, Chris Whitty, issued a government Press Release reiterating that 'we all agree that the risk to the UK public remains low' (Whitty 2020a). The same phrasing was repeated by the Health Secretary on 24th January (Reuters 2020), and again in various government communications on 27th January (e.g. Hancock 2020a).

On 3rd February, Johnson made a speech in Greenwich that played on familiar themes of British exceptionalism in order to justify keeping the country open for trade. In it, he argued that other nations' overreactions to coronavirus threatened the global market economy, and explained that he intended the UK, which he compared to Superman, to buck this trend:

'there is a risk that new diseases such as coronavirus will trigger a panic and a desire for market segregation that go beyond what is medically rational to the point of doing real and unnecessary economic damage, then at that moment humanity needs some government somewhere that is willing at least to make the case powerfully for freedom of exchange, some country ready to take off its Clark Kent spectacles and leap into the phone booth and emerge with its cloak flowing as the supercharged champion of the right of the populations of the earth to buy and sell freely among each other ... I can tell you in all humility that the UK is ready for that role'. (gov.uk 2020e) 
On 10th February, a slight shift appears to have taken place, with the Secretary of State declaring that 'the incidence and transmission of novel coronavirus constitutes a serious and imminent threat to public health' (gov.uk 2020a). Nevertheless, mandatory screening was still not taking place at borders-in fact only 273 out of the 18.1 million people arriving in the UK in the three months prior to the lockdown were quarantined (Grieirson 2020) —and as late as 20th February, Downing Street was continuing to reassure the public that 'the risk to individuals remains low' (Rawlinson et al. 2020). On 12th February, an Exeter University study warned that 45 million people in the UK could become infected if the virus was left to spread. On 14th February, Johnson was apparently so relaxed about the developing situation that he took a holiday for almost a fortnight in the Kent countryside with his new fiancé, during which time he seems to have finalised his divorce, and aides were told to 'keep their briefing papers short' (Calvert et al. 2020, April 19). Richard Horton, editor of The Lancet was later to point out that 'we knew in the last week of January that this was coming, the message from China was absolutely clear ... we wasted February when we could have acted' (in Evans 2020).

Later in February, studies emerged that showed that a large percentage of those infected were asymptomatic, and on 2nd March, another alarm bell was sounded after two consensus statements were reported to SAGE, alerting them to the high likelihood of 'sustained transmission of COVID-19 in the UK at present', and warning them that without more 'stringent measures' an estimated $80 \%$ of the population would become infected, and that their 'best estimate of the infection fatality rate is in the range of $0.5-1 \%$ ' (SPI-M-O 2020). This translated into an almost unthinkable death toll of between 250,000 and 530,000 British citizens. However, this warning was apparently insufficient to budge the government from its low mimetic reading of events, which they continued to project for two further weeks. That same day Johnson's final words in a video address to the nation were strangely edited out of the version that was published on the government's social media accounts. He stated: 'I wish to stress that, at the moment, it's very important that people consider that they should, as far as possible, go about business as usual' (in Calvert et al. 2020, May 24).

The day following this SAGE meeting, Johnson held his first press conference, televised to the nation. Flanked by the scientific authorities of Chris Whitty and the Chief Scientific Advisor, Patrick Vallance. This opening scene would be an opportunity to set the tone for the ensuing drama and define the characteristics of its narrative genre. Whitty's relaying of the $80 \%$ infection rate might have provoked some gesture towards 'narrative inflation', the process 'through which ramping up ... of threats is achieved' (Smith 2005, p. 29). However, any increase in the 'weighting' (Alexander 2012, pp. 35-39) offered to the coding of the virus as a significant threat was quickly undone by Whitty's reassurance that 'the proportion of the population who get infected is likely to be lower than that and probably a lot lower than that ... even for the highest risk group, the great majority of people will survive this ... If you're talking about the low-risk groups, the rate of mortality is well below 1 per cent' (in Menendez 2020). The general performance that day was coherent, and Johnson reassured the gathered journalists that this was 'overwhelmingly a disease that is moderate in its effects' (in Calvert et al. 2020, May 24). 
If these efforts at retaining a deflated narrative had failed to achieve their end, and any of the assembled journalists risked leaving the conference with the impression that the story to be reported was anything more than routine political management, Johnson's memorable subsequent intervention left no room for doubt. 'I was at a hospital the other night where I think there were actually a few coronavirus patients and I shook hands with everybody', he declared, offering the relaxed advice that 'we should basically just go about our normal daily lives', and that 'the best thing you can do is wash your hands with soap and hot water while singing Happy Birthday twice' (in Crace 2020). Frye uses 'domestic tragedy' as another term for the low mimetic mode, and it would be difficult to contrive a more mundane and domestic proposal than washing one's hands with soap and water.

A concerned Downing Street source was later quoted in The Sunday Times telling them: 'the handshake-you can't minimise how important that is' (in Calvert et al. 2020, May 24), and a SAGE member was quoted in the Guardian saying that at this point it became clear that a gap had emerged between 'the scientific advice and political messaging. "The prime minister was going around shaking people's hands to demonstrate that there wasn't a problem. There was a disconnect at that point. We were all slightly incredulous that that was happening"' (Conn et al. 2020).

On 28th February, the first death of a British national occurred on the quarantined Diamond Princess cruise ship, and the Sunday Times reported that around the same time Dominic Cummings (Johnson's Chief Advisor, and former director of the successful Vote Leave campaign) had 'outlined the government's strategy' for the UK's national response to the virus 'at a private engagement', quoting those present as claiming that it was 'herd immunity, protect the economy, and if that means some pensioners die, too bad' (Shipman and Wheeler 2020). Given the subsequent prominence of this 'herd immunity' term-and given the government's later denials that it was ever informing their strategy - it is worth briefly reviewing its presence in the UK's response, and how neatly it fit with their initial low mimetic narrativization of events.

\section{‘Herd Immunity'}

It's not possible stopping everyone in the population getting it. And it's also, actually, not desirable, because you want some immunity in the population - Prof. Patrick Vallance, Chief Scientific Advisor to the government, 12th March, 2020.

Following Cummings's reported private outlining of a herd immunity strategy, it wasn't until early March that the idea was launched into the public sphere and became subject to the mechanisms of civil discourse.

Its most (in)famous airing was Johnson's memorable reference to the concept on ITV on the 5th March, the same day that confirmed infections exceeded 100 and the first COVID death on UK soil occurred. Asked by the presenter whether the plan was 'to spread this out so it doesn't all happen at once and overwhelm the NHS', Johnson revealed that 'one of the theories is that perhaps you could take it on the 
chin, take it all in one go and allow the disease, as it were, to move through the population, without taking as many draconian measures' (This Morning 2020).

Actions, of course, speak louder than words, and Johnson put this 'theory' into performative practice by shaking the presenter's hand (who had intentionally kept it by his side to see if Johnson would offer his own) on entering the studio. When asked about this during the interview, Johnson responded 'I've been going around hospitals as you can imagine and always shake hands. People make their own decisions' (in Ng 2020; Mason 2020d). Background representations (low-mimetic generic narrativizations of the virus) were being converted into concrete scripts (Mast 2013, p. 10), which were then being made to walk-and-talk on the public stage provided by a daytime TV show. Performance, in other words, was being creatively deployed to communicate the government's intended meanings for the virus.

Johnson's symbolic actions (Burke 1966) continued to accord with the 'theory' he had shared with the nation when two days later he was photographed at a Six Nations rugby match at Twickenham, with tens of thousands of fans in attendance, after which he retweeted a video of himself again shaking hands with the England team (England Rugby 2020). It was later revealed by The Times that Johnson had failed to attend any of the five crisis response COBRA meetings that took place in January and February (Calvert et al. 2020, April 19), ${ }^{2}$ and which are typically chaired by the PM at times of national crisis (A. Walker 2020; Walker 2020a, b).

On a BBC broadcast on 11th March, David Halpern, a behavioural psychologist and SAGE member who leads Whitehall's Behavioural Insights Team-commonly known as the 'nudge unit'-first offered the public a label to attach the 'theory' that Johnson had both verbally explained and then performatively acted out. Halpern's unit draws upon 'nudge theory', used by many liberal democratic governments as a way of 'nudging' citizens towards 'better' choices (such as handwashing during the C19 outbreak) in a way that avoids legislative intervention. Whilst it raises its own civil liberties issues, it is a mode of applied behavioural psychology that lends itself well to civil libertarian modes of government. On the $B B C$ News that day, Halpern described a strategy of 'cocooning' vulnerable groups, for a period of time during which the virus could spread, so that 'by the time they come out of their cocooning, herd immunity [could have] been achieved in the rest of the population' (in Easton 2020). The idea was to avoid a second, possibly worse, outbreak in the autumn or winter if too few had developed immunity by then. Two days later, on the BBC's most popular radio news broadcast, the Today Programme, Patrick Vallance reiterated that 'our aim is to ... not suppress it completely; also, because the vast majority of people get a mild illness, to build up some kind of herd immunity so more people are immune to this disease and we reduce the transmission' (in Stewart and Busby 2020). Later that day he told Sky News that $60 \%$ of the population (approximately 40 million people) would need to become infected in order to reach herd immunity, accepting that this would involve 'an increasing number of people dying' (Vallance 2020). It is worth noting how death is presented here in regrettable but hardly highdramatic tones. Frye associates low mimetic drama with pathos (1957, p. 38), and

${ }^{2}$ These meetings derive their name from taking place in the Whitehall Cabinet Office Briefing Room A. 
pathos allows death to be framed as regrettable, though not something that actors have a great deal of agency to control. As Boltanski (1999) has argued, feelings of pity for those that suffer or die might move us, but they rarely evoke action towards ending the causes of that death or suffering. Death was being framed here as unfortunate, but ultimately unavoidable.

The dominant signification of a 'herd' is livestock, and whatever the technical meaning, the popular semantic implication was that human health was being managed equivalently to cattle. This risked evoking eugenicist connotations that are clearly distasteful to many. Lawrence Freedman (2020) wrote that the term 'lent itself to accusations that the government was preparing to let the disease rip through the community as part of a cold-blooded experiment in social engineering'. Moreover, the science was not clear that long-term antibody resistance was viable, an assumption that was based upon the idea that this new virus would operate in a similar way to influenza (Conn et al. 2020). Although new influenza viruses keep mutating, they are somewhat predictable in that individuals are known to develop immunity through vaccination or exposure. Less is known, by contrast, about how the human immune response to $\mathrm{C} 19$ functions, and how long it lasts, so deciding not to suppress or track it involved far higher levels of risk.

On 13th March, two other SAGE members confirmed that herd immunity was the only available option. Prof John Edmunds told Chanel 4 News that there were two approaches to stopping a virus: 'you can stamp out every case in the world', but, 'we haven't managed to do that ... when the genie is out of the bottle, the virus is all around the world and spreading, the only other way that the epidemic is going to come to a stop is achieving herd immunity'. Prof Graham Medley, interviewed for the BBC, stated that 'we're going to have to generate what we call "herd immunity", so that's the situation where the majority of the population are immune to the infection, and the only way of developing that in the absence of a vaccine, is for the majority of the population to become infected' (on Newsnight 2020).

However, it was not only the scientists' references to the idea, or Johnson's conspicuous actions in accordance with that idea, but also wider policy decisions during this period that offered an overall unity to the government's initial narrativization. All three of these elements were working performatively in concert with the others. On 10th March, the same day that Nadine Dories, a Health Minister, tested positive for the disease, the government claimed that there was no scientific basis for suspending sporting events or other large gatherings. Many looked on in disbelief as the Cheltenham Horse Racing Festival - an event that was cancelled in 2001 due to the foot-andmouth-disease outbreak (a virus that can in only very rare conditions infect humans) took place unabated. One-quarter of a million racing enthusiasts attended from 10th to 13th March. Local cases 'increased several-fold' soon afterwards (Tucker and Goldberg 2020; Sabbagh et al. 2020). Most attendees travelled to Cheltenham from other areas of the country, where they of course returned following the event, an unknown number carrying the pathogen with them. Two horse-racing fans who had attended Cheltenham died with C19 symptoms on the same day at the end of that month (Calvert et al. 2020, May 24). On 11th March - the same day that the Director General of the WHO formally declared a 'pandemic' and expressed that the organisation was 'deeply concerned by .... the alarming levels of inaction' exhibited by some governments (WHO 
2020b) - approximately 3000 Atletico Madrid fans flew from Madrid-a coronavirus hotpot, which was itself already under partial lockdown-into Liverpool to attend the Champions League tie (Proctor 2020). This was at a time when Atletico Madrid had been forced to close its home ground due to the virus (Dispatches 2020). Liverpool soon becomes another UK infection hotspot (Nuki 2020). Giant Stereophonics gigs were held in Glasgow (11th March), Manchester (13th March), and Cardiff (14th March) —in arenas with a combined capacity of over 40,000_producing memorable images of tightly packed fans. All these areas subsequently experienced spikes in cases, but for the time being, this large-scale imagery served to provide manifest symbols of the government's narrative that there was little high drama in this outbreak, no need for ritual to redress it, and that life should continue as normal.

Contrast heightens dramatic effect and the sense of doing nothing during this period was exaggerated by news that comparable countries were actively intervening to halt the virus's spread. This was a pandemic, not a local epidemic, and the British story was merely a subplot in a global drama. The domestic audience had access to a global media to inform their judgement of how convincing the government's narrative was. East Asian nations had demonstrated the efficacy of mass testing, contact tracing, and stockpiling protective equipment, and equivalent European governments were projecting divergent stories that refused to countenance the enormous death toll associated with a 'herd immunity' strategy. Italy, Denmark, Ireland, Norway, and Spain had all entered lockdown in early March. Germany had heeded the successful South Korean experience, carrying out comprehensive testing and contact tracing. By 12th March, France had announced school closures, and banned large public gatherings. ${ }^{3}$ On 13th March, the behavioural advisors to SAGE put the case that public trust in the government's response would be lost 'if measures witnessed in other countries are not adopted in the UK' (quoted in Freedman 2020).

Much of the public and many private institutions clearly felt the dominant national narrative was not changing quickly enough and legitimacy in the government's story appears to have diminished around mid-March. ${ }^{4}$ Polling published on 14th March revealed that $41 \%$ felt that the government was underreacting to the situation, and only $36 \%$ trusted what Johnson said on the subject (Helm 2020). Internal government polling showed that a majority was now in favour of cancelling large sporting events (Freedman 2020). Preceding government instructions to do so, the Premier league, the Football League, and the Women's Super League all suspended their fixtures indefinitely on 13th March, in spite of the enormous financial cost of these moves (MacInnes 2020). Financial services professionals were told to work from home after outbreaks appeared in their offices (Clarke 2020; Reuters 2020), anxious parents kept their children away from school (Murphy 2020), employees began simply refusing to show up to work, and universities began cancelling face-to-face teaching from 13th

\footnotetext{
3 The French newspaper Liberation reported that Macron threatened to close borders to British nationals, provoking Johnson's decision to enforce lockdown later in the month.

${ }^{4}$ Party preference polls show the Conservatives continuing to poll high at this point, but this was a period during which the Labour's leadership election was simultaneously being held (24th February-4th April), and therefore in which party divisions were being publicly aired in order for the candidates to differentiate themselves.
} 
March, advising students who could do so, to return home as soon as possible (BBC 2020f). Large sectors of the public were refusing to act out their roles in the low mimetic narrative in which they had been cast. After lockdown finally arrived, The Telegraph quoted a Cabinet member claiming that they 'didn't want to go down this route in the first place-public and media pressure pushed the lockdown' (Rayner et al. 2020). Leadership and agency were emerging from below, and the government risked being inadvertently cast as a follower, rather than a leader.

On 14th March, a WHO scientist criticised the 'herd immunity' approach on Radio 4's Today programme, emphasising the need to escape the notion that events should simply run their course, and instead pleading the importance of becoming actors in the unexpected drama: 'we can talk theories, but at the moment we are really facing a situation where we have got to look at action' (in Financial Times 2020; also Cockroft 2020). That same day, an open letter, signed by over 500 scientists was published, pressing the government to recognise its capacity to resist the enveloping disaster: "the growth can be slowed down dramatically, and thousands of lives can be spared ... "herd immunity" at this point does not seem a viable option ... additional and more restrictive measures should be taken immediately, as it [sic.] is already happening in other countries across the world' (Open Letter 2020a). Another open letter signed by almost 700 behavioural scientists had been published the day previously, likewise, highlighting the country's 'unique window' for action. This letter took aim at the assumption that 'behavioural fatigue' could justify failing to implement lockdown, arguing that 'essential behaviour changes that are presently required (e.g. handwashing) will receive far greater uptake the more urgent the situation is perceived to be. "Carrying on as normal" ... undercuts that urgency' (Open Letter 2020b). All these interventions were united in their linking narrative inflation with an increase in perceived agency over unfolding events.

\section{Towards narrative inflation}

On 12th March, a highly significant SAGE meeting took place in which the development of the virus in Italy - which the UK was tracking in terms of case and death rates-was put under focus, and the extraordinary consequences of sticking to a 'herd immunity' approach were apparently acknowledged. In Turner's typology, this moment at last marked recognition amongst those in power that the viral breach had developed into a crisis (Turner 1980, p. 150). In Aristotle's language, this was the moment of 'recognition', the moment of 'change from ignorance to knowledge' (Aristotle 1996, pp. 18-19). Dominic Cummings was present at this meeting and was reported by the Sunday Times to have suddenly realised that 'he had helped set a course for catastrophe', resulting in what the newspaper described as a 'Domoscene Conversion" (Shipman and Wheeler 2020).

That same day, Johnson, in a much more sombre mood, and seemingly uncomfortable with having to share the bad news, made a striking announcement that signalled a radical break from his previous public communications. He stated that 'this is the worst public health crisis in a generation... It is going to spread further, and I must level with you, I must level with the British public: many more families are 
going to lose loved ones before their time' (Stewart et al. 2020). He announced that the government would be moving from its 'contain' to its 'delay' stage (gov.ac.uk 2020b). Acting against WHO advice to 'test, test, test' it was also announced that testing those with symptoms and the minimal efforts that had taken place to contact trace would be abandoned. Additional advice was offered, but it was modest, and still merely advice-those exhibiting symptoms should stay at home for 7 days, over 70s were advised not to go on cruise ships, and schools should not take their pupils on trips abroad (Stewart et al. 2020). Levels of human agency, in other words, remained low: though recognition had occurred, and a crisis had been inaugurated, a reversal in action and an initiation of redress was yet to come.

That Saturday, 14th March, the Cabinet met and agreed to escalate the response. An attendee reported that the 'mood in the room was astonishing. You could tell that something very significant had shifted' (in Shipman and Wheeler 2020).

That same day, denials began of what had, a few days earlier, appeared transparent. The Department of Health issued a statement that 'herd immunity is not part of our action plan, but is a natural by-product of an epidemic' (Ghosh 2020), and the health secretary wrote an article for the Sunday Telegraph claiming that '[h]erd Immunity is not our goal or policy; it's a scientific concept; our policy is to protect lives' (Hancock 2020b). ${ }^{5}$

Even though the UK epidemic was doubling every three to four days at this point, it was nine more days until lockdown-a policy that jarred with Johnson's libertarian impulses - was enacted. This decision to delay had demonstrably fatal consequences for many, as the government's own advisors identified (Mason 2020b). Modelling from Imperial and Oxford Universities (in Calvert et al. 2020, May 24) suggests that if lockdown had commenced on 3rd March, when the initial dire warnings concerning 'mitigation' were presented to SAGE, infections would have needed to be brought down from around 14,000. By Saturday 14th March, when the decision to change approach arrived, around 200,000 people were infected. By the time lockdown was enforced on 23rd March, infections were estimated to be around 1.5 million. Another piece of research for Channel 4 suggests that locking down on 12 March would have led to 13,000 fewer deaths, and on 16th March, 8,000 fewer (Dispatches 2020). The starkest estimate, however, has come from the epidemiologist and mathematical biologist Neil Ferguson, a former SAGE member who heads the Imperial College COVID-19 response team that has advised the government throughout the crisis. On 10th June, Ferguson told a House of Commons Science committee that if the government had locked down a week earlier, "we would have reduced the final death toll by at least a half' (Stewart and Sample 2020).

\footnotetext{
${ }^{5}$ Further evidence of the brazen nature of these denials comes from the following: the Italian Health minister reported that Johnson had phoned the Italian PM on 13th March, telling him explicitly that herd immunity was the strategy (Dispatches 2020); an author of a paper widely credited with influencing the government's change of approach (Ferguson et al. 2020) explained at its launch that 'we were expecting a degree of herd immunity to build up ... we now realize it's not possible to cope with that in the current health system, and it may not be acceptable in terms of the numbers' (in Conn et al. 2020); interviewed on 25th March on BBC Breakfast, the former Health Secretary stated that the government changed 'from a herd immunity approach to a suppression approach about ten days ago'.
} 


\section{Phase II: inflation to the high mimetic mode}

This section will describe how the government's belated recognition that they had made a catastrophic miscalculation led to narrative inflation to a high mimetic mode. Most of this new narrativization took place within the genre of tragedy, which Aristotle describes as 'an imitation of action that is serious, complete, and of a certain magnitude' (1996, p. 10). A central motif of this inflation was the increasing use of militaristic metaphors, which lent themselves to moral polarisation by magnifying the threat presented by the virus to the level of a belligerent invader. This legitimated the need for the extraordinary state intervention required to enter the liminal lockdown phase on 23rd March. It also provided a thematic frame for ritual activity by recasting those who were charged with directly tackling the virus into the role of national 'heroes', apparently willing to risk sacrificing their lives for the health of the nation. At the same time, the government attempted to recast the scientists as more responsible for government policy than the government itself. This narrative inflation reached its peak with Johnson's admission into hospital with the virus, a moment that moved the story from the tragic genre of drama, to the even higher romantic genre of legend, imbuing Johnson with superhuman powers to fight off the viral antagonist. The end of this section will describe how relatively soon after Johnson's release from hospital, signs of narrative deflation emerged, paving the way for a slow and incomplete return to an ambiguous low mimetic mode, characterised by anticipations of both partial reintegration and schism.

On 19th March, Dominic Cummings met with the government's communications director, the general election campaign director, the election's social media strategist, a PR boss, and various figures from the Vote Leave campaign, to devise the government's main slogan to define the second high mimetic period of the COVID drama (Hope and Dixon 2020; Shipman and Wheeler 2020). This group had been involved in the famously effective 'take back control' mantra for the 2016 Brexit referendum, and the Tory's similarly successful 'Get Brexit done' slogan for the 2019 general election. The new slogan they created to form the centrepiece of the messaging for the lockdown period was 'Stay home. Protect the NHS. Save lives.', and it was released on Friday 20th March, two days before lockdown was officially enforced.

In announcing lockdown on 23rd March, Johnson emphasised the final element of the slogan: 'I must give the British people a very simple instruction: you must stay at home'. This announcement constituted what Aristotle called peripeteia, or reversal, the moment in a plot in which 'there is a change to the opposite in the actions being performed' (1996, p. 18). In Turner's schema, this reversal in actions initiated the most important period of a social drama, that of redress, in which various mechanisms - such as closure of businesses and public buildings, but most centrally an unambiguous order to the public to 'Stay Home' - were brought into operation to resolve the crisis and bring the recently elevated viral antagonist to heel. The tripartite slogan was repeated over and over again in speeches and government messaging on television, the radio, billboards, and across social media, including being plastered on the front of the lecterns from which the daily press conferences were held (Fig. 4). 
On the second day of lockdown (24th March), for the first time in British history, an SMS with the slogan was sent to every UK mobile phone, and later that week, a letter from the Prime Minister containing the slogan was sent to every household in the UK. Its appearance was typically surrounded in 'emergency' red and yellow chevrons, signifying the seriousness and urgency of the instruction. Emphasising the inflation of agency intended by the slogan, Hope and Dixon (2020) quote a senior Downing Street source as explaining that it 'was built around the concept of emergency so people could appreciate how stark times were. We needed action'.

The action called for, however, was not action from the government, but from the public, and as will be explored below, this contributed to an attempt at shifting responsibility that was to define this high mimetic lockdown period. Ironically enough, other than for those few engaged in essential services, the action called for was also a kind of inaction: 'Stay Home' was how this invisible antagonist was to be fought.

\section{War metaphors}

Like the casting that takes place in situated performances, and the narrative genres that social dramas yoke themselves to, metaphors are another method of meaningmaking, and the metaphor of war was increasingly used by the government and media in discussions of how the virus would be 'fought'. All this 'war talk' (Roy 2003, pp. 1-7) served the purpose of narrative inflation, justifying the extraordinary state powers required to enter lockdown.

The war alluded to most frequently was that war that currently holds pride of place in the fractured British conscience collective. This was of course WWII, and the fact that the 75th anniversary of VE Day fell within the crisis no doubt primed the receptiveness with which this allusion was met. Turner has pointed out that 'the culture of any society at any moment is more like the debris, or "fall-out," of past ideological systems, than it is itself a system, a coherent whole' (1974, p. 14), and the collective memory of WWII-a war which the vast majority of living people in the UK never experienced first-hand-has become an established culture structure within the British nationalist mythopoeia, capable of conjuring formidable feelings associated with overcoming adversity, and just victory over evil. Sometimes sentimental, sometimes jingoistic, this reference is typically backward-looking ${ }^{6}$ or even melancholic (Freud 1917, pp. 243-258; Gilroy 2005, pp. 88-89) and follows the same route of binary polarisation demanded by genre inflation. As Gilroy has put it, the imaginative invocation of WWII allows Brits to 'know who we are as well as who we were, and then become certain that we are still good while our uncivilised enemies are irredeemably evil' (ibid.). In the C19 'war', non-human agency featured in the form of the 'invisible enemy' being cast as the antagonistic virus itself.

\footnotetext{
6 The controversial Nairn-Anderson thesis proposed an explanation for British culture's backward-looking tendencies in its incomplete bourgeois revolution, which accommodated itself to the ancien régime, rather than overthrowing it (Anderson 1964; Nairn 1964; cf. Thompson 1965).
} 
The following words/phrases are all taken from newspaper front-page headlines referring to C19 during the period under study: 'the Blitz', 'Army', 'Victory, 'bulldog spirit' (accompanied by an image of Churchill giving the victory sign), 'Betrayal', 'Battle', 'war footing'. The top five ministers of the government have repeatedly been referred to as the 'war cabinet', words like 'threat', 'battle', 'fight', 'invisible enemy', were used repeatedly in the press conferences, during which Johnson also described the NHS as 'unconquerable' (12th April). Once lockdown was imposed, these martial binaries were used to identify 'traitors' flouting its rules (The Mirror 2020). However, the war imagery was not always bellicose: the hospitals built to deliver extra ICU capacity were called 'field hospitals', volunteers producing PPE were described as working on the 'home front' (Blackall 2020), and during an extraordinary televised speech to the nation, the Queen alluded to Vera Lynn's famous WWII song 'we'll meet again'.

Some of the metaphors, whilst not quite subliminal, were less explicit, so that even if they were not always consciously recognised, they nevertheless retained their power to strike the 'symbolic imagination in more or less the same way' (Baudrillard 2002, p. $41 \mathrm{n} 1$ ). References, for instance, to the sites where infections were understood to have originated as 'epicentres', or the routine description of those staff dealing directly with infected patients as 'frontline' seemed to operate in this way.

War did not only feature in language, but also in ceremonial actions that became the focus of media attention and public celebration or censure. A veteran WWII British army officer, Captain Tom Moore, walked 100 laps around his 25-m garden in the run up to his 100th birthday to raise money for the NHS during lockdown. Moore, who completed his circumambulations using a walking frame and adorned with his war medals, provided an immaculately preformed icon for the broader sense of wartime spirit the government was working to evoke. He went on to record a version of Lynn's 'we'll meet again' to raise further money for charity, and Johnson sent him a recorded birthday greeting from Downing Street, referencing the 'heroic efforts' he had made to complete his 'mission', later recommending him for a knighthood. More contrived attempts at military ceremony were not so successful, such as the Health Secretary's announcement on 16th April that a lapel badge would be provided to care workers, describing it as 'a badge of honour in a very real sense, allowing social care staff to proudly and publicly identify themselves' (in Wood 2020). In a situation in which deaths were mounting amongst these workers, ersatz medals were perceived by many as an insulting substitute for adequate PPE provision, and the scheme was widely ridiculed (Woods 2020).

Successful wars are typically good for political fortune, but unsuccessful ones can spell ruin for a government's authority. Deploying these affective metaphors as ciphers through which to understand the virus therefore simultaneously opened up political risk, since references to the same civil code could be used to critique, as well as to defend government policy. One consultant cardiologist who contracted the disease but could not access testing complained that 'there is policy of surrender' (in Boseley 2020a). An epidemiologist suggested that if we were at war, the government needed to do better, in 'commissioning, or commandeering supplies, and delivering those supplies under fire ... appoint a commander and give them powers 
to requisition equipment and laboratory space ... Make a battle plan on who should be tested first' (Hunter 2020). Critics pointed out that the government's newfound martial courage was effectively locking the stable door after the horse had bolted, recasting them from war heroes to appeasers. As one critical website put it, Johnson was 'not Churchill. He's Chamberlin' (www.appeasement.org).

Of course, there is nothing particularly new about politicians and the media using war metaphors ('trade wars', 'war on drugs', 'war on poverty', etc.). They are perhaps the most frequently used metaphors of all, and their ubiquity means we often fail to detect them. Their popularity is no doubt due to their readily understandable nature, and their tried-and-tested ability to trigger emotions and summon symbolic boundaries between us (the allies) and them (the enemies) (Lamont and Molnár 2002). Moreover, these metaphors have a long association with illness and disease in particular (Sontag 1978), entering our consciousness from a young age (sick children are frequently told to 'be a brave soldier'). Nerlich (2020) suggests that war metaphors are 'the go-to metaphors used in almost all reporting on infectious diseases' in particular, where pathogens are said to 'invade' cells, 'colonise' their host, and our natural 'defences' are said to become 'compromised', 'conquered', or 'overwhelmed'. One explanation for this strong association might be that infectious diseases operate on a microscopic scale, invisible to the naked eye. Metaphors provide a vivid visual imagery that allows us to assimilate and structure our understanding of these invisible but highly consequential forces, to make sense of how they operate, but most importantly, what they mean, since ' $[\mathrm{m}]$ etaphor is, at its simplest, a way of proceeding from the known to the unknown' (Turner 1974, p. 25).

Nevertheless, such metaphors do not arise spontaneously, and there was nothing inevitable about the truculent imagery that was attached to the $\mathrm{C} 19$ events. The doctor in Camus's La Peste notes that a plague is similar to other human evils in that it 'helps men to rise above themselves' (Camus 2002 [1946], p. 96). Given the extraordinary outpouring of community solidarity in response to the COVID threat, metaphors of cooperation and mutual support might just as easily have been adopted. Despite historical associations and factoring in the mores that shape and socialise our decision-making, the choice of war metaphors must ultimately be considered just that: a choice. It should also be noted that just as tying real-life events to generic narratives simplifies a complex reality, metaphors likewise tend to conceal whilst they simultaneously reveal. This is because 'metaphor selects, emphasizes, suppresses, and organizes features of the principal subject by implying statements about it that normally apply to the subsidiary subject' (Turner 1974, p. 30). Whilst rhetorically effective, metaphor can at the same time therefore curtail and distort our comprehension of the principal subject. Wars, for instance, are fought via top-secret strategies laid out by the commanders of sovereign nation-states. Pandemics are not. Containing and eliminating viral outbreaks requires cooperation, transparency, and maximal sharing of information. Rendering pandemics symbolically as if they were wars allows national governments to avoid transparency, to suspend normal democratic accountabilities, and to ignore the experiences and advice proffered by other nation-states, or by global health organisations.

Nevertheless, in spite of all these reductions and misrepresentations-and perhaps in fact because of them-metaphor remains a potent symbolic resource. The 
choice to use warfare as the primary figurative representation of fighting the COVID threat had the important effect of inflating the sense of danger, and therefore expanding the powers available to the government to control it. A cultural intervention, in other words, enabled a public health intervention. In war-whether real of metaphorical - as in tragedy, heroes come to the fore, and the following section will explore the role that the figure of the hero played in meaning-meaning during this phase of the crisis.

\section{Heroes}

In ancient Greece, heroes were considered somewhere between the Gods and the mortals, and their memories were often kept alive via ritual forms of worship, including offerings and sacrifices that took place around their burial mounds or shrines (Farnell 1921). Heroes were of course also the main protagonists of Greek drama in the high mimetic mode; they were the 'somebody doing something' (Frye 1957, p. 33), typically presented as struggling against adversity, often driven by higher moral motives. The great Greek tragedies frequently centred around, or concluded with, the hero's death, even if those deaths were rarely represented directly to the audience (Pache 2009). Very soon into the COVID19 outbreak, NHS and other key workers-many of whom had previously been referred to in derogatory terms as 'low-skilled', 'inefficient', 'greedy', and 'selfish' (e.g. McKinstry 2011)—were recast as honourable 'heroes' throughout the British media and in speeches and press briefings issued by the government. This section will discuss how this recasting enabled a reframing of the meaning of these workers' deaths.

Rosenberg notes how epidemics tend to take 'on the quality of pageant, mobilizing communities to act out proprietary rituals that incorporate and reaffirm fundamental social values and modes of understanding' (Rosenberg 1989, p. 2). Various secular rituals sprung up around the newly cast heroic healthcare workers in the UK, included children drawing rainbows, often accompanied by slogans of thanks to NHS staff, and sticking them in their windows to be seen by passers-by.

There was also a minute's silence held on 28th April for what the BBC described as 'fallen key workers' (BBC 2020a). The choice of a minute's silence, and the description of those that had died as 'fallen' is lifted directly from war commemoration, and in ritualised memories of war, death is dramatised as heroic, but casualties are nevertheless considered inevitable. As one NHS worker bluntly put it 'calling us heroes makes it OK when we die' (Panorama 2020). Similar metaphorical work was at play in the US, where Trump usefully spelled out what British leaders intimated. In an off-script section of a speech delivered in Pennsylvania, Trump observed that 'healthcare warriors' were 'running into death just like soldiers run into bullets', adding — as if savouring the moral aesthetic — that 'it's an incredible thing to see, it's a beautiful things to see'. It scarcely needs stating that no healthcare worker entered their career on the understanding that they may be required to sacrifice their lives. 
Durkheim (1995) discusses how intensely emotional interactions focused around sacred objects arise in response to symbolic threats to a community, their functional purpose being to reconfirm collective bonds at moments when their solidity is waning or placed in danger. This approach to ritual spawned an influential paradigm in British anthropology (e.g. Radcliffe-Brown 1965), but one that in its focus on collective solidarity, weighed too heavily towards the explanation of ritual's functional role in maintaining stasis rather than triggering change, or at least limited its conception of change to immanent systemic causation. Turner (1969), by contrast, whose ethnographies of the Ndembu exposed extraordinary levels of conflict amongst these village communities, placed more emphasis on ritual's-and eventually social drama's - role in not only reconfirming but also transforming social structure. In this sense, Turner is perhaps best conceived as a conflict theorist, who developed the metaphor of social drama to explain how conflicts resolved themselves through socially patterned processes. Nevertheless, although Turner's preoccupation is with the management of outbursts of social conflict, he nonetheless studied such phenomena to gain deeper insights into the ongoing 'deep structures' that are revealed through analysing the surface ruptures (1974, p. 34). The rituals that took place during the UK C19 outbreak were both triggered as responses to a collective threat, but nevertheless expressed social division as much as solidarity, and anticipated change as much as conservation.

The most prominent ritual that arose, for instance, was one initiated by Annemarie Plas, who imported the practice of regularly clapping for healthcare workers that she had seen take place in her home-country, the Netherlands. Successful cultural practices tend to 'reproduce themselves' (Wagner-Pacific and Schwartz 1991, p. 413), and the ceremony was rapidly and widely adopted in the UK, with hundreds of thousands of participants clapping key workers from their windows, balconies, or doorsteps during lockdown, celebrating and consolidating their heroic status in the national imaginary. Durkheim had observed the importance of periodically repeating rituals 'to renew their effects' (1995, p. 420), and 8 pm on Thursday evenings quickly establishing itself as the time in which the rite would be enacted. During the structureless, liminoid days of lockdown, the ritual also provided a way of connecting with neighbours in a collective expression of shared sentiment. Reminiscent of prison protests, participants who were not necessarily able to see one another in person, could nevertheless hear each other in cacophonous waves of sound that spread an audible 'bond of communitas' across residential centres (Turner 1969, p. 105). Collective participation, however, did not miraculously resolve the contradictions that underlay this ritual.

For many on the political left of British society, the NHS has been a sacred object of veneration since its postwar foundation, and its staff have been consecrated as folk heroes by those who have relied upon their care. Participation in such public reconfirmations of sentiment were therefore unsurprising when expressed from these quarters. What was surprising was the public participation of some quite unlikely sectors of British society. Johnson, for instance, had on multiple occasions backed private provision of healthcare, and in 2002 attacked the idea of sacralising the NHS in a speech in which he called for its 'reform', stating: 'I don't see why it should be sacrilegious to say that the NHS is failing ... It's all very well to treat the NHS as a religion but it's legitimate for some of us to point out that insofar as it is 
a religion it is letting down its adherents very very badly' (in Bartlett 2019). Yet Johnson made sure he was filmed every Thursday evening engaging in the clapping sacrament. Other Tory MPs who had voted through legislation defunding the NHS for almost a decade when the virus hit had also been filmed cheering in the House of Commons after successfully voting down an amendment that would have given NHS nurses a pay rise. They too, however, advertised their enthusiastic participation in the clapping ritual on social media with hash tags such as \#YouAreHeroes (e.g. Helen Whately 2020). Even within the C19 crisis, on 18th May, Tory MPs backed an immigration bill denying so-called 'low-skilled' workers-which included many of the 'heroes' they had been clapping-being granted UK work visas. The same month it was revealed that the $£ 60,000$ provided to families of bereaved NHS workers would not be extended to families of care home workers or hospital cleaners who had lost loved ones. The Daily Mail, who had dedicated various front pages in 2016 to attacking junior doctors striking over unsafe working conditions (12th February; 25th, 28th April; 31st August; 3rd September), and in 2014 had felt it necessary in another front-page headline to inform the public that ' 4 in 5 Nurses on NHS Wards are Foreign' (Dec 17th 2014), similarly joined in the public thanksgiving, boasting of the $£ 1$ million it had raised via a charity for what it described as the 'NHS heroes' in its 29th April front-page headline.

One way of explaining this apparent ritual convergence is that the NHS has successfully been raised to a sacred status within the British civil sphere, and its positive coding has been established as a 'common-sense' across the mainstream political spectrum (Gramsci 1971, p. 326 f5). As a result, politicians who care about their careers must be seen to be protecting and supporting it. This is especially so at a time of national crisis in which healthcare workers were narrativized as primarily responsible for fending off the collective threat. Another element of an explanation might come from narrative inflation having meant that the virus was successfully coded as the primary antagonistic enemy, and as any war-mongering leader knows, external threats can temporarily and precariously galvanise internal solidarities. Finally, Griswold (1987) recognises that successful cultural expressions allow their consumers to project diverse meanings upon them, whilst simultaneously retaining some overall coherence. The same is evidently true of cultural practices: those that enjoy widespread participation in complex societies with deep political divides need to function somewhat like Rorschach inkblot tests, allowing varied participants to read their own meanings into them, whilst maintaining some broader sense of formal unity. Getting at the same thing from a different angle, Laclau (1996) might have described the functional role of such practices as akin to 'empty signifiers' - signifiers without firm signifiedswhich in their openness to resignification become focussed sites for political struggles over meaning. In the case of the Thursday \#Clap4Carers, participants often creatively moderated the rite in order to emphasise the particular meaning it held for them. An ex-mining union leader and Labour MP, for instance, was filmed banging a saucepan, chanting 'pay them properly; give them PPE'. As Wagner-Pacific and Schwartz (1991, p. 417) point out, rituals 'do not resolve historical controversies; they only articulate them, making their memory public and dramatic'. This insight was on display most clearly on the event of the UK's final \#ClapForCarers, on 28th May, for which a group of healthcare workers gathered outside the Downing Street gates. As the PM emerged 
to clap from the steps of No. 10, the group turned their back on him, holding a sign reading 'Doctors, not Martyrs', and stood in silence for 237 s, one second for each of their colleagues who had died from the disease. ${ }^{7}$

\section{Establishing 'free-floating' responsibility}

The narrative inflation brought about through the use of these war metaphors functioned both to excuse the death of healthcare workers and to increase legitimacy for the interventionist policies that the government had belatedly chosen to deliver. Another function, though, was to distribute responsibility for dealing with the crisis away from elected officials. Although wars are directed by generals, they are fought by troops, and Johnson made clear that it was the British public who were being called up for national service: 'in this fight we can be in no doubt that each and every one of us is directly enlisted. Each and every one of us is now obliged to join together, to halt the spread of this disease' (Johnson, 23rd March).

Thanking others for their role in delivering an outcome implicitly casts these flattered inductees into some degree of responsibility if that outcome turns out to be wanting. Here, as in the casting of NHS workers as 'heroes', interpellation can be seen most clearly in the use of gratitude and adulation as a mechanism of power. If we recall the improv advice that 'volunteers must be treated with love and generosity' (Johnstone 1981, p. 14), we can see how thanks and praise increases the likelihood that an actor will recognise themselves in their assigned role, and that casting will be effective. When faced with criticism, government statements would be issued defending their own actions in the same breath as thanking the public for theirs. For instance, in response to whether the government had any regrets concerning their handling of the crisis, one Downing Street spokesperson insisted:

'we have taken the right steps at the right time to combat it, guided by the best scientific advice. We are so grateful for the response of the public, who have helped us to slow the spread of the virus' (in Conn et al. 2020).

Unlike cruder versions of scapegoating, the implicit—and indeed structuralcorollary of the idea that it was the public's responsibility for winning the war was that it was also, at least in part, the public's responsibility if the war was lost. Politicians can typically rely upon the mass media to amplify deviance, and such reports often tend not so much to inform the public of actual news, as to provide them with periodic reminders of society's moral boundaries (Erikson 1966). Just as convenient 'folk heroes' had been discovered in figures such as Captain Tom Moore, 'folk devils' were quickly identified too (Cohen 1972). This more sinister element of the framing borrowed from another dramatic genre- the 'open conflict of good

\footnotetext{
7 This protest was itself in part a 'spillover effect' (Mayer \& Whittier 1994) or reiteration of an established repertoire of resistance (Morgan 2018) from a protest in Belgium, where for the same reasons as in the UK, healthcare workers had turned their back on their PM during a hospital visit in Brussels (Mathers 2020).
} 
Fig. 2 Tweet from Boris

Johnson's private account, 9th

May, 2020

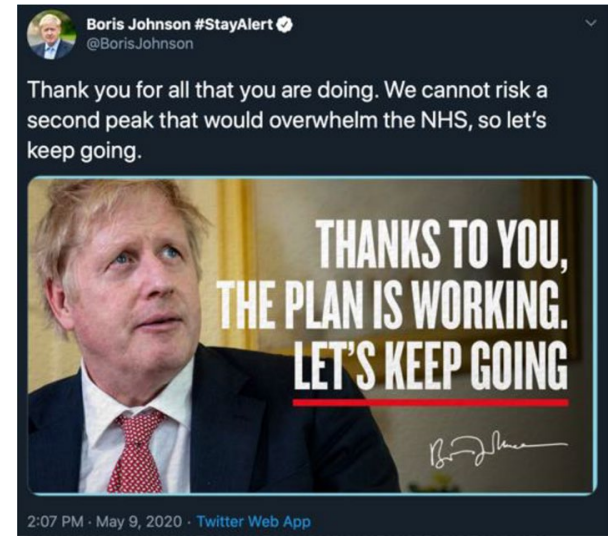

and evil' (Frye 1957, p. 290) found in the medieval morality play. ${ }^{8}$ Pulling against any superficial galvanising force found in the ritual processes described above, this allowed for identification of 'enemies within', and the coding of these figures as morally corrupt. News reports focussed on the public's flouting of the lockdown rules (e.g. Goorwich 2020; BBC 2020b; Osborne 2020), encouraging transgressions to be reported to authorities (e.g. Higham 2020). Sun bathers in public parks, for instance, were attacked by the government and the media for undermining the fight against collective suffering and paraded in the media as public examples of one of 'the shapes that the devil can assume' (Cohen 1972, p. 10). Asked on BBC Radio 4 why people were ignoring the government advice, the Health Secretary responded, 'well I don't know, because it's very selfish' (Mason 2020a). As we shall see, these assertions came back to haunt the government when it was discovered that their senior advisor had himself spectacularly breached the rules.

On 9th May, just prior to the second major shift in genre, Johnson tweeted 'Thanks to you, the plan is working, let's keep going' (Fig. 2). This 'keep going' refrain was repeated in various other social media posts from Johnson's personal and official accounts. Beyond shifting responsibility onto the public's shoulders, a climate of 'free-floating responsibility' (Bauman 1989, pp. 161-163; Cohen 2000, p. 88) was established in other ways too. The health secretary shifted responsibility to NHS medical staff for over-using PPE (Stewart and Campbell 2020), 'huge global demand' was held responsible for PPE shortages (Lay and Wright 2020), 'Chinese culture' was responsible for creating the virus (Liu 2020), but most consistently and explicitly, scientists were held responsible for the overall strategy of the response.

Turner (1969, pp. 166-203) discusses how liminal periods allow for changes in traditional status and role distinctions, which is in part how ritual processes are able to deliver social transformation. The 'following the science' mantra allowed MPs who had been elected to bear responsibility for public decision-making to

\footnotetext{
${ }^{8}$ Wagner-Pacifici (1986) shows how this genre played out in the social drama that arose around the kidnapping and killing of Aldo Moro in 1978.
} 
shift this responsibility by recasting themselves as simply servants to science. Interviewed on Sky News about the alarming levels of infection in care homes following revelations that 1,500 elderly hospital patients had been transferred into care homes and the community without being tested, the Work and Pensions Secretary said 'if the science was wrong, the advice at the time was wrong, I'm not surprised if people will then think we then made a wrong decision' (in Merrick 2020). Hume (1985, pp. 507-521) famously argued that you cannot derive an 'ought' from an 'is', and it is clear that prescriptive policy cannot be read directly off descriptive science. To turn science into policy, interpretation and decisionmaking must intervene, and interpretation is a fundamentally cultural matter (Taylor 1971; Geertz 1977), just as political decision-making is a fundamentally normative matter. During the outbreak, significant_and for many, deadly_lags took place between evidence appearing and evidence being acted upon, suggesting that it was not scientific calculations, but political and economic ones-themselves deeply embedded in the normative worldview of those politicians making them-that were leading the response.

Different 'sciences' were also played off against one another. 'Behavioural science', for example, was used as a justification for ignoring measures that epidemiological science might have suggested necessary. In early March, Johnson had chaired his first COBRA meeting of the crisis, in which he was presented with the shocking 500,000 deaths scenario, following which, many members of the medical science team were shocked that tougher restrictions were not immediately introduced (Dispatches 2020). Chris Whitty justified delaying such measures on the basis that 'if we go too early people will understandably get fatigued' (in Cohen 2020), and Hancock later delivered the same line adding that 'social science and the behavioural science are a very important part of the scientific advice that we rely on' (in Conn et al. 2020). However, the behavioural scientists advising the government strongly rejected this notion of 'fatigue' (ibid.), as did other independent behavioural scientists (Open Letter 2020b), placing a question mark over its origins as part of the government's strategy.

'Guided by the science' was usually shorthand for the fact that they were relying on the Scientific Advisory Group for Emergencies (SAGE), a body charged with providing impartial scientific advice to the government. The daily press conferences were staged in such a way that there was almost always a scientist from this group, or usually two, on a podium by the MP or PM who was fielding the questions. At first, the composition of SAGE was kept secret, but its membership was later revealed by the Guardian newspaper. Anthony Costello, a doctor and ex-director of the WHO, critiqued the group not only for drawing upon too narrow a range of expertise, but also for the fact that 13 of its 23 members were directly employed by the government (Costello 2020). It was soon revealed that the top government advisor, Dominic Cummings, was also sitting in on SAGE meetings, alongside another younger political protégé of his (Carrell et al. 2020). Costello (2020) argued that this vastly reduced the likelihood of free disagreement. Sir David King, the former Chief Scientific advisor, was 'shocked' by the revelation that political advisors had attended, stating that 'if you are giving science advice, your advice should be free of any political bias' (in Carrell et al. 2020). 
Vallance had claimed on 13th March that 'I speak scientific truth to power' (Sky News 2020), yet available evidence does not seem to bear this claim out. Minutes from a SAGE subcommittee meeting on 3rd March (SPI-B 2020) stated that they had reached 'agreement that government should advise against greetings such as shaking hands and hugging' (in Payne and Cookson 2020; Mason 2020d). Vallance then stood by Johnson's side in the press conference that same day whilst he boasted of being 'at a hospital where there were a few coronavirus patients and I shook hands with everybody ... I think the scientific evidence is, well, I'll hand over to the experts', Johnson said, gesturing towards Vallance. Vallance failed to correct the PM, simply advising, 'wash your hands'.

Rifts had apparently developed between the government and the scientists when on 19th March, Johnson had-in the absence of any scientific evidence-claimed that they could 'turn the tide' of the virus within 12 weeks, a statement that had apparently 'appalled' the experts (Shipman and Wheeler 2020). Prof. Neil Ferguson (the lead author of the Imperial paper that it was claimed provoked the government's shift in approach) made clear that 'it was the politicians, not the scientists, who decided on policies to pursue' (in Conn et al. 2020). Another key SAGE member, Prof Graham Medley, claimed that although the scientists advised the government, action was ultimately 'a political decision', agreeing with the interpretation that Johnson and Hancock have sometimes been 'passing the buck' onto the scientists (in Con et al. 2020).

The former examples in this section showed the role of flattery in the exercise of interpellative power in shifting the responsibilities inherent in democratic office onto the shoulders of the public or healthcare workers. These latter examples, by contrast, show the role of office itself in moving the locus of responsibility from elected and democratically accountable officials to unelected and unaccountable experts. The claim of simply 'following the science' allowed MPs to cast themselves in what Bauman, drawing upon Milgram, called an 'agentic state', a heteronomous condition in which actors present themselves as simply 'carrying out another person's wishes' (1989, p. 162).

\section{A romantic interlude: Johnson falls ill}

On 10th March, Nadine Dorries, a health minister, tested positive for COVID-19. On 25th March — two days after lockdown had come into effect-so too did heir to the throne, Prince Charles. On 27th March, Prime Minister Johnson also tested positive, alongside the Health Secretary, Matt Hancock. Chris Whitty, the Chief Medical Officer, also started experiencing symptoms the same day. On 5th April, Johnson was admitted to hospital where he would spend seven nights, three of them on an intensive care ward where he was not intubated but was given oxygen treatment. Three days later, Dominic Cummings also developed symptoms. The fact that the virus had penetrated the inner sanctums of the symbolic 'centres' (Geertz 1977) of British society, infecting almost all the top officials charged with controlling it, naturally generated enormous media attention. This fuelled genre inflation further, to the point that the suspense story of Johnson's 'Fight for Life' - as the 7th April front 
pages of both the Daily Mirror and Daily Star described it-was eventually elevated to the romantic mode.

The romantic mode presents the hero as superior not in kind but in degree to other mortals, and 'the ordinary laws of nature [as] slightly suspended', so that 'prodigies of courage and endurance, unnatural to us, are natural to him' (Frye 1957, p. 34). On 8th April, the Daily Mail and the Daily Express both ran with a front-page headline lifted from a speech made by Foreign Secretary Dominic Raab asserting that 'Boris is a Fighter... He'll Pull Through'. Raab, who was deputising for Johnson, had declared the day earlier that 'I am confident he will pull through because if there is one thing I know about this Prime Minister, he is a fighter'. Heads of foreign states echoed Raab's claims, Narendra Modi asserted that 'you are a fighter, and you will overcome this', and Donald Trump reassured everyone that 'He's very strong, resolute. Doesn't quit, doesn't give up'. On 9th April, The Sun, pointed to various political elections Johnson had won, editorialising that he 'has overcome the odds before and can do so again' (Dunn and Dathan 2020). There was, of course, nothing automatic about this construction of meaning, and it is worth comparing it with the initial agentless narrativization of the UK's response to the virus described above, and even the predominant tragic narrative of this period. In the former mode, death was a regrettable inevitability for which pathos was the dominant 'structure of feeling' (Williams 1977, pp. 128-135); in the latter, the disease might be challenged on a policy front, but death could hardly be warded off through individual force of will.

Frye describes how the romantic mode is characterised not only by 'the suspension of natural law' but also 'the individualizing of the hero's exploits' (1957, p. 36), and this new spotlighting of Johnson as capable of somehow fighting the virus by sheer strength and courage, cast a shadow over the agency of the NHS staff who were treating him. It also implied that others who had died from the virus were simply not resolute enough in their 'battle'. Sontag describes how this notion of a patient beating disease through individual effort is a common theme especially for cancer patients, and emphasises the added turmoil it can cause for the sufferer. 'Widely believed psychological theories of disease assign to the ill the ultimate responsibility both for falling ill and for getting well' (1978), she wrote. Interestingly, the responsibility for falling ill—given Johnson's previous handshaking gambles-was rarely assigned to him, but the responsibility for getting well certainly was.

Smith's (2005, p. 20) claim that heroes' motivations become more ideal as narrative inflation takes hold is also borne out in this example. On 4th May, The Sun's Front Page reported on an exclusive interview with the headline 'Baby Gave Me Will to Live', in which Johnson-who has refused to publicly disclose how many children he in fact has-described how 'the fear of never seeing his unborn son gave him the strength to beat coronavirus' (Wooding 2020).

\footnotetext{
9 Mirroring Geertz's (1977, pp. 140-141) description of the Sultan of Morocco's ministers concealing his deterioration and eventual death, as Johnson's condition worsened and he 'was gasping for breath, aides insisted at a lunchtime press briefing that he was busy working ... Dominic Raab, even claimed Johnson was in charge and "leading"" (Harding et al. 2020).
} 
Another theme of the narrativization of these events was that of democratisation: the notion that key public figures contracting the virus indicated its acting as a great social leveller. A Downing Street source claimed that the 'stay home' slogan's 'success was to communicate a message that "we are all in this together"' (in Hope and Dixon 2020). In the daily press conference on 27th March (the day of Johnson's diagnosis), Cabinet Office minister Michael Gove suggested that the 'fact that both the prime minister and the health secretary have contracted the virus is a reminder that the virus does not discriminate'. On 28th March, The Mirror's front-page headline ran 'Virus at Heart of govt. Nobody's safe'. On 17th April, The Telegraph's front page was a full spread reading 'All in, all together', calling on readers to stay at home.

Again, there was nothing inherent in the events that necessarily determined these meanings-when Iran's deputy health minister had contracted the virus, it was widely reported in the UK press as signalling the incompetence of the Iranian government in managing the outbreak.

The government's reading of events quickly found themselves subject to dispute. On BBC's Newsnight on 9th April 2020, for instance, the presenter began the show with a segment that quickly went viral on social media:

'They tell us that coronavirus is a great leveller. It's not. It's much much harder if you're poor.... those working on the frontline right now, bus drivers and shelf-stackers, nurses, care home workers, hospital staff and shopkeepers are disproportionately the lower paid members of our workforce. They are more likely to catch the disease because they are more exposed'.

She added that 'you do not survive the illness through fortitude and strength of character, whatever the Prime Minister's colleagues will tell us ... this is a myth that needs debunking'. The presenter's views were backed up by evidence. The crisis has been experienced in radically different ways depending upon one's housing, employment, and income situation. The wealthier have been more likely to be able to work from home, enjoy household and garden space, and the IFS has shown that richer households have actually increased wealth during lockdown through spending less on luxuries; an effect that has not been seen for poorer households (Crawford et al. 2020). There has also been a starkly disproportionate number of BAME deaths from C19 in the UK (Pareek et al. 2020).

Even Johnson's particular episode was a poor emblem for social levelling: he was tested when others in his condition and age group had no access to testing, and a source in the hospital even claimed that since he had not required a ventilator, he 'was taking up an ICU bed when he didn't need it' (in Harding et al. 2020). Once he was released from hospital, the travel restriction that applied to everyone else apparently did not apply to him, and he spent his recovery in a grace-and favour 16th Century Manor House outside of London, with an indoor pool, surrounded by 600 acres of land.

Perhaps contrary to what might be expected, the episode of Johnson's illness coincided with the second largest increase in support for the government's handling of the crisis during the outbreak (YouGov 2020a, b; Opinium 2020; Fig. 3). Legitimacy was high throughout this middle period of redress, partly because government 


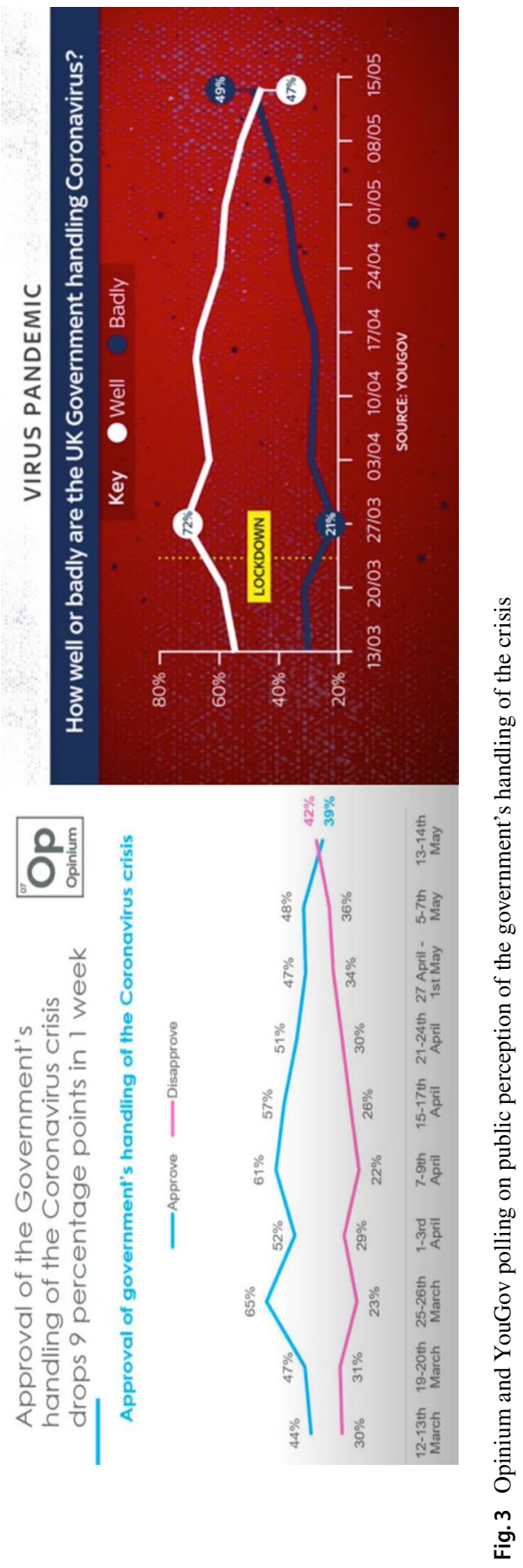

我 
actions appeared to be conforming to their projected definition of the situation, which itself coincided with dominant public answers to the question of 'what is it that's going on here?'. This specific uptick in legitimacy in a prevailing climate of high legitimacy can in part be explained through the romantic narrative around Johnson's illness, and the consequent recalibration of the level of agency available for dealing not only with Johnson's personal health, but with the public health crisis more broadly. Jacobs and Smith (1997, p. 68) identify how within civil societies, romantic narratives 'encourage maximal participation, solidarity, and trust in a common political culture' promoting the assumption of 'powerful and overarching collective identities'. Tying groups together in collective projects, driven by shared sentiments and generative of communal identities are processes that are likely to overshadow the more mundane dissensus that might rise to the surface of political life under less elevated narrative genres. As with civil ceremony and ritual, the dramatisation of external threats can serve to temporarily increase internal solidarities, but such solidarities are fragile and time-bound, and cannot be assumed to hold under altered narrativizations. As incoherencies emerged between the government's definition of the situation and their public performances, as their casting of the primary antagonistic threat shifted, and as the narrative pitch was wound down again, dissensus would soon reappear, and with it, legitimacy would soon fall.

\section{An unexpected assailant?}

In Johnson's first speech on emerging from hospital, after claiming that the government's response had been a 'success' (exactly one week before Britain's death toll became the second highest in the world), he referred to the virus in criminal terms, as a 'physical assailant, an unexpected and invisible mugger', claiming that 'we have begun to wrestle it to the floor' (28th April). ${ }^{10}$ In evoking this 'mugger' imagery, a deflation of tone was inaugurated. The signification of the virus as an unpleasant threat remained, but it was no longer the grand foreign invader that had animated the military metaphor. The virus was being recast in the government's projection as once again a more mundane antagonist that could be-indeed was being-wrestled to the floor. The object of struggle was once again becoming more localised and domesticated, and the powers of action ascribed to the virus-with the structural correlate being also those powers necessary to tackle it-were losing their extraordinary force. Johnson's particular emphasis on this mugger as 'unexpected' was latched onto, provoking some angry public responses.

On social media, a clip from a popular Channel 4 TV programme, Gogglebox, in which participants are filmed reacting to TV broadcasts, went viral. Responding to

\footnotetext{
${ }^{10}$ Much of Johnson's political charisma is built upon his figurative and - to his admirers-entertaining, use of language. During the crisis, flattening the infection curve became 'squashing the sombrero', avoiding an infection peak was travelling through a 'vast Alpine tunnel', and Johnson referred to the regional lockdowns as 'whack-a-mole'. This often-clownish use of imagery has alienated as much as it has entertained though, as occurred in his reported use of the phrase 'Operation Last Gasp' during a meeting to source extra hospital ventilators (Blanchard 2020).
} 
Johnson's 'unexpected mugger' comment, one viewer asks rhetorically, 'it wasn't really that unexpected though, was it?', another reacts that 'we saw this coming over the hill from China, so I don't think it was that much of a surprise'. 'If we're going to use that simile, that's like a mugger skipping down the street, doing a little dance number, and a twirl, singing "I'm going to mug yooou!", says another viewer in the clip, with his sofa companion adding, 'that's like saying Jack the Ripper was unexpected after he'd killed his fifth prostitute'.

These viewers were undoubtedly correct in their assessments. C19 was unprecedented in all sorts of ways, but its arrival—or the arrival of something similarwas certainly not unexpected. Since 2008, the government's own National Risk Register had ranked pandemic influenza as one of the highest national risks to the UK, stating that 'experts agree that there is a high probability of another influenza pandemic occurring', and that 'one half of the UK population may become infected and between 50,000 and 750,000 additional deaths' (Cabinet Office 2008, p. 13). An updated version of the same register in 2017 put pandemic influenza in both the highest risk category, and the most likely civil societal risk to take place (Cabinet Office 2017). The newer report stated that 'emergency responders have personal protective equipment for severe pandemics and infectious diseases' and that there are 'protocols in place for infection control both before and during an incident' (ibid., p. 35).

In 2016, however, a secret government simulation had been carried out for a hypothetical influenza pandemic, codenamed Exercise Cygnus, which had instead shown that the NHS would collapse under lack of resources including inadequate levels of PPE (Nuki and Gardner 2020). Although C19 is not an influenza virus, the PPE required is identical, and that the government were supposed to have been stockpiling this equipment in accordance with their own risk assessment. They failed to do so. Stock went out of date without being replaced during the austerity years (Malik 2020), and fell in value by $40 \%$ ( $£ 325$ million) (Davies et al. 2020). At the end of 2019, there were also 43,000 nursing vacancies in the NHS (Gallagher 2019). No protective gowns at all were included in the government's stockpile when COVID hit, even though the government's own advisors had recommended stockpiling in 2019 (Panorama 2020). Nor did the government buy any visors, swabs, or body bags (BBC 2020c). Even in the absence of this stockpile, however, there was still time to source what was necessary and build up ventilator capacity. On 7th February, the European Centre for Disease Control had issued clear guidance about the levels of necessary protective equipment required (ECDC 2020) meaning that if the UK had acted then, they could have sourced what was needed. British companies who made PPE had written to the government offering their services but received no response (BBC 2020d), so many of these companies actually began exporting their products to foreign governments, such as the USA (Panorama 2020). The UK failed to join two rounds of EU schemes to bulk-buy PPE, and one to buy ventilators, claiming that that they had missed the invitation emails (Boffey and Booth 2020; Mason and O'Carroll 2020). Johnson had promised that 'we'll give them [NHS staff] all the support that they need; we'll make sure that they have all the preparations, all the kit that they need for us to get through it' (This Morning 2020) but images of NHS staff re-using disposable gear, wearing old swimming goggles, 
'dinner lady' aprons instead of the recommended long-sleeved gowns, and making protective head gear from bin-liners and plastic shopping bags quickly surfaced (e.g. Staton et al. 2020). Families of NHS workers and volunteers dug out old sewing machines and began making scrubs for their loved ones, and members of the public with 3D printers began producing masks (Blackall 2020; ITV 2020). The government then explicitly ordered coroners not to investigate lack of adequate PPE in the inquests into NHS workers' deaths (Booth 2020).

Most alarmingly perhaps, on 18th March (i.e. following the government's decision to inflate the narrative and introduce far more interventionist social isolation measures), a press release from Public Health England announced that as of "19th March, 2020, COVID-19 is no longer considered to be a high consequence infectious disease (HCID) in the UK' (gov.uk 2020c). This was an extraordinary decision to make at the height of the deadliest viral outbreak in living memory, especially four days prior to lockdown coming into effect, and at a period where deaths were mounting exponentially (Calvert et al. 2020, April 19). The classification had direct implications for PPE guidance-for a HCID, medical workers should be supplied with an appropriate long-sleeved gown, a respirator mask, and a visor-and it appears that this downgrading was the government attempting to protect itself from litigation, conscious of inadequate PPE supplies (BBC 2020c).

On 5th May, even on the official figures released by the government-which have almost certainly vastly underestimated the real death toll (Giles 2020)_British deaths from the virus became the highest in Europe, and the second highest in the world, with a higher proportion of deaths than the country with the worst overall death toll in the world. Only five days after these ignominious rankings however, narrative de-escalation began translating into policy.

\section{Phase III: deflation back to an ambiguous low mimetic mode}

This final section describes the third phase of the government's response to the virus, which entailed a winding down of the drama back to an ambiguous low mimetic mode. This involved a significant and much-criticised shift in the government's official slogan, and a change in its policy towards the easing of lockdown restrictions and the encouragement of a return to work. At the level of meaning, where the antagonistic threat had previously been focussed purely on the virus itself, the threat was now broadened to also include the consequences of over-responding to the virus through a 'long period of enforced inactivity'. This section will describe how public approval dropped markedly during this period, arguing that this resulted in large part from generic and performative incoherence. The final subsection describes the most spectacular instance of this performative incoherence by recounting the story of how the architect of the 'Stay Home' slogan found himself caught in the act of failing to stay home whilst infected by the virus.

On 5th May, The Telegraph reported a senior adviser to the Prime Minister as claiming to have 'a phase two messaging plan pretty much ready to go. ... We are going to remove "stay at home" because that is not going to be the main focus of things. It is about moving people onto the second part of the journey' (in Hope 

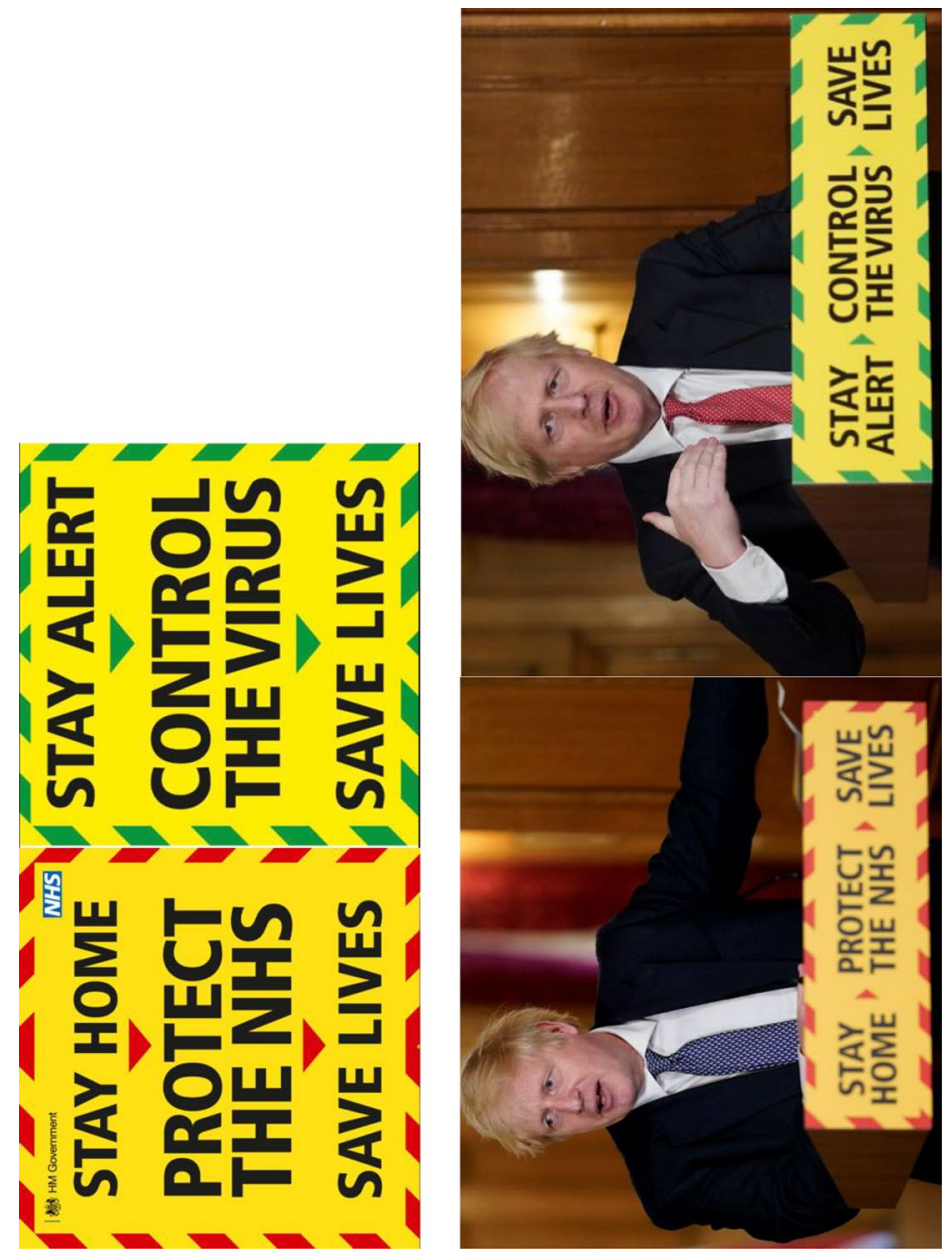

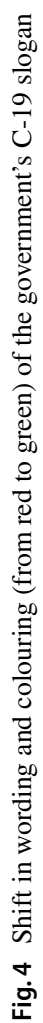


and Dixon 2020). Describing what I have chosen to define as the third phase of the response, as 'phase two' or the 'second part of the journey', was a presentation later repeated by Johnson, and one that conveniently removes the government's failure to act during the initial period from view.

On 10th May, Johnson released a speech from Downing Street in which he announced a loosening of lockdown restrictions, including requesting those who could not work from home to return to their workplaces, the removal of any limitations on outdoor exercise, and the announcement that certain school classes could return from 1st June (gov.uk 2020d). Though not entirely coherent, this announcement appeared to signal the beginning of the end of the liminal period of redress, and a movement back towards structural reintegration. In his speech, Johnson introduced the new tripartite slogan that would define this third period: 'Stay Alert. Control the virus. Save Lives.'. The shift in the design of the slogans was also notable (Fig. 4). Whereas the old one had been surrounded by red chevrons, the new slogan was surrounded by green ones; the semiotics of the message was clear-the country was shifting from 'stop' to 'go'.

The new messaging was immediately criticised as confusing and incoherent (Bush 2020; Tolhurst 2020; Sheridan 2020; A. Walker 2020; Walker 2020b), and the devolved Scottish, Welsh, and Northern Irish governments all refused to shift from the original slogan. Public health communications during a deadly viral outbreak need to be clear and comprehensible and this new slogan was evidently not (Mendick 2020), since it was unclear what the public were being asked to "stay alert' to. Polling showed that whilst $91 \%$ of the public understood the old slogan, only $30 \%$ understood the new one (YouGov 2020b). This was arguably not a communications error, as many PR experts were quick to claim (Hickman 2020), but instead an extension of the free-floating responsibility theme mentioned above, achieved through a successful communication of an intentionally incoherent message. The purpose, in other words, was arguably to encourage a loosening of restrictions whilst passing responsibility for the possible consequences of that loosening further onto individuals. Evidence for this reading comes from the multiple times during Johnson's address that he thanks the public_-it was 'thanks to your effort' that the death rate was coming down, and 'thanks to you' that thousands of lives were saved (gov.uk 2020d; Johnson 2020).

The speech included a clear pivot to recasting the antagonistic threat from being not only the disease itself, but also the consequences of radical responses to the disease: 'there are millions of people who are both fearful of the disease, and at the same time fearful of what this long period of enforced inactivity will do to their livelihoods and their mental and physical wellbeing ... this campaign against the virus has come at colossal cost to our way of life' (ibid.). This recasting of the virus introduced an ambiguity that had not previously been present over what exactly it was that the public should be 'fearful' of. After all, Johnson continued to describe the virus in the morally polarised terms of high mimetic tragedy as a 'vicious threat', and even used the apocalyptic and religious imagery of 'sacred-evil' (Alexander 2012, pp. 56-59) at one point, referring to 'this devilish illness' (gov.uk 2020d). These proclamations, however, were contradicted by the broadening out of the metaphors used to describe the antagonist (from 'foreign invader' to 'mugger'), the 
ambiguity as to what the primary threat in fact was (was it the virus, or the 'cost to our way of life' incurred by controlling the spread of the virus?), and by the rolling back of the restrictions that had previously been in place.

In spite of the continuing refrain that the new plans were 'driven by the science' (gov.uk 2020d), the shift again appears to have been led by politics. The top scientific advisors were never asked to sign off on the slogan (Campbell et al. 2020), and Prof. John Dury, who sits on the behavioural subcommittee of SAGE typically tasked with devising public communications during emergencies asked 'Who is advising on the current messaging? Unfortunately, it's not us', criticising the 'Stay Alert' messaging as 'too vague' (in ibid.). Later in May, another prominent SAGE advisor, Prof. John Edmunds, issued a warning that 'with relatively high incidents, and relaxing the measures, and with an untested track and trace system, I think we are taking some risk here' (in Boseley 2020b).

The day following Johnson's announcement of the lockdown loosening, teachers unions spoke out against sending classes back on 1st June, and a petition asking for parents to retain the right to keep their children at home gathered 390,000 signatures (Lovett 2020). On 15th May, the Daily Mail front-page headline attacked 'militant unions' for standing in the way of teachers wishing to return to work, and in continuity with the sacrificial-heroic coding of the previous period declared 'LET OUR TEACHERS BE HEROES'. Four days later, The Guardian reported that 1,500 primary schools were intending on defying the government's orders to open at the beginning of June (Weale et al. 2020).

Three days after Johnson's lockdown loosening speech, polls indicated a 9-point plunge in public approval of the government's handling of the crisis, with disapproval $(42 \%)$ for the first time during the crisis exceeding approval (39\%) (Opinium 2020a; Fig. 3). A repeat poll on 21st May showed this disapproval with the handling of the crisis growing, as well as Johnson's personal approval rating being overtaken by the opposition leader (Opinium 2020b). The same polling found that $47 \%$ of the public believed that the government were underreacting to COVID-19, compared to $34 \%$ who believed they were reacting proportionally, and that $43 \%$ of parents felt anxious sending their primary-aged children back to school, compared to $20 \%$ who felt relieved; $53 \%$ felt anxious sending their secondary school children back, with only $13 \%$ reporting relief (ibid.).

It is important to ask why it was, during this third period in which the government attempted to move the country back towards structural reintegration, that public legitimacy fell below the levels seen even at the end of the initial period when institutions and individuals were leading the government towards lockdown (Fig. 3). One important factor was a lack of both generic and performative coherence.

In terms of genre, whilst many successful dramas are based upon blending (tragicomic, romantic-comedy, etc.), and whilst genres can be shifted from one mode to another, genre constraint nevertheless exists, since genres are indeed generic and therefore do not exhibit unlimited plasticity or boundless synthetic potential. This genre constraint might be thought of as one of the ways in which the relative 'autonomy of culture' functions. The ambiguities described above-in narrativizing what the real threat was (was it still the virus? was it now the effects of countering the virus?), at what level of gravity this threat should be understood, what powers of 
agency existed to fight the virus, and indeed what the new messaging condensed in the revised slogans in fact meant-flouted generic rules leading to broad confusion as to the kind of story the government was trying to tell. During the initial low mimetic period, a growing proportion of the public may not have found the government's narrative genre convincing, but there was at least coherent projection to disagree with. No such coherence reigned during this third period.

On the performative level, in the first period Johnson had acted in accordance with low mimesis by shaking hands and allowing sporting events to go ahead, communicating that it was 'business as usual' (Calvert et al. 2020, May 24). In this third period, Johnson was mixing the rhetoric of one genre (the high mimetic claims that this was a 'devilish disease' [gov.uk 2020d]), with the actions of another (the low mimetic loosening of lockdown restrictions so as to 'reopen society' [ibid.]). Such incoherence threatened the possibility of widespread fusion, and less of the public seemed prepared to suspend their disbelief and go along with the confused narrative they were being told.

Such contradictions between word and deed reached their most spectacular apogee in an episode revealed near the end of May. This episode, which occupies the focus of the following and final subsection, further eroded the dramatic force of the government's intended projection, damaging legitimacy even further.

\section{Cummings and Goings}

On 22nd May, a joint investigation by The Guardian and The Mirror revealed that Dominic Cummings had breached the lockdown rules he had helped write after being spotted at the end of March on the grounds of his parent's home in Durham, a county in the North of England, 264 miles away from his London home (Crerar and Armstrong 2020; Weaver 2020). His presence in Durham would have violated lockdown rules if he had been feeling well, but the transgression was considered particularly serious since both Cummings and his wife had written about their coronavirus illnesses during this period, omitting to mention their extensive trip (Wakefield 2020). At the height of the lockdown, and exhibiting symptoms, they had apparently travelled the majority of the length of the country from the most infected zone to an area with a relatively low infection rate at the time. By this point, the official advice had been tattooed into the public's consciousness by the extraordinary communications campaign Cummings himself had designed: Stay Home, and if you showed symptoms, you should self-isolate for seven days.

The next day, a government minister, Grant Shapps, made clear that although the Cummings family had made the cross-country trip, he had 'stayed put' once there (Bland 2020). The following day, however, a member of the public reported spotting the Cummings family at Barnard Castle, 45 min from Cummings's parents' home (Weaver and Dodd 2020).

Rather than apologise for the incident, the government chose to double-down, using an appeal to the higher moral motive of love for one's child, as the alibi. Downing Street issued the following statement on the day the story broke: 'Owing to his wife being infected with suspected coronavirus and the high likelihood that he 
would himself become unwell, it was essential for Dominic Cummings to ensure his young child could be properly cared for' (in Stewart and Weaver 2020). The public had by this point spent weeks restricting their movements. Thousands who had contracted the virus had been confronted with the same childcare issues but nevertheless conformed to the lockdown instructions. For many others adhering to the lockdown rules had meant foregoing saying goodbye to dying loved ones and being unable to conduct funeral ceremonies. Many scientists, and even Tory MPs were furious with the official response, and began joining calls from the opposition benches for Cummings to resign or be sacked.

The following day, a remarkably similar chorus of messages in support of Cummings appeared on cabinet ministers' social media accounts. An instance of this came from the Health Secretary tweeting that 'It was entirely right for Dom Cummings to find childcare for his toddler, when both he and his wife were getting ill'. On 3rd April, whilst Cummings was away in Durham, that same Health Secretary had presided over the daily press conference, behind a podium with the inconspicuous words 'Stay at Home' emblazoned upon it and stated that 'we cannot relax our discipline now. If we do, people will die', warning that 'this advice is not a request, it is an instruction' (BBC 2020e). The government's narrative risked appearing as though it had been devised only to apply to the public and not to the government itself, a case of 'do as we say, not as we do', which undermined the earlier 'we're all in it together' framing of the outbreak.

Since the media seemed unprepared to let the story die, the following day Johnson held a press conference claiming that Cummings had 'acted responsibly, legally and with integrity', again deploying the higher moral motive argument in claiming that 'any parent would understand'. Many parents did not understand though, and the headlines that day were the worst since Johnson's premiership began. The Mirror had headshots of Cummings and Johnson, with 'A Cheat \& A Coward' splashed across their front page. Even the Daily Mail-typically unwavering in its automatic support for the government-ask incredulously of the pair, 'What Planet Are They On?'. Prof. Stephen Reicher, a member of the SAGE behavioural subcommittee, tweeted that 'in a few short minutes tonight, Boris Johnson has trashed the advice we have given on how to build trust and secure adherence to the measures necessary to control COVID-19'. Dr Adam Kucharski, of SAGE's modelling subcommittee, tweeted that for the contact tracing measures 'to work, we need public adherence to isolation/quarantine to be very high. But I fear it's now going to be far more difficult to achieve this'.

As the pressure mounted, it was announced that Cummings would give his own press conference the following day (25th May) from the Downing Street Rose Garden, an unprecedented move for a Senior Advisor, which the BBC described as an 'extraordinary piece of political theatre'. In a gesture that no doubt did little to help generate sympathy and diffuse the impression of arrogance, Cummings kept the audience waiting for half an hour, pushing back the day's TV scheduling. When he finally emerged, remorse was nowhere to be seen: 'I believe in all the circumstances I behaved reasonably and legally'. To a journalist's question of whether he regretted his actions, he responded 'No, I don't regret what I did'. To a question about whether he had considered resigning, the answer again was 'no'. Precedent had been 
set by the Scottish Chief Medical Officer and the author of the Imperial paper, both resigning from their roles for far less serious transgressions of the government's rules. Cummings justified his journey due to the 'exceptional circumstances' around his childcare, but tens of thousands of people had found themselves in far worse circumstances, and nevertheless kept to the rules. He also confirmed his trip to the scenic town of Barnard Castle, which, entirely coincidently, had fallen on his wife's birthday. He claimed he had made the journey to test his eyesight, which had apparently been damaged by the disease, to see if he was fit to drive back to London. This decision to operate machinery for an hour and a half in lieu of an eye-test would have been odd if it had only meant putting himself at risk, but having done so with his family in the car, in the same defence in which he claimed that his overall actions were driven by the higher moral motives of love for his child, tried the credulity of many observers. After it was revealed that Cummings's wife also held a driving licence, a reader wrote to The Guardian suggesting that the reason her licence had not been used to drive the family home was probably that the dog had eaten it (Guardian Letters 2020).

A poll published in the Daily Mail the following day revealed that whilst $8 \%$ believed Cummings's eye-test story, $78 \%$ took it to be false (Hussain 2020). The same poll suggested that $59 \%$ of Tory voters thought he came across as arrogant, and a staggering $80 \%$ of Conservative voters believe he had broken lockdown rules. $70 \%$ agreed with the statement that Johnson's government believes 'it's one rule for them and another rule for everyone else', with $65 \%$ predicting it was less likely that others would now follow the lockdown rules. A YouGov poll the same day revealed that $52 \%$ of Leave voters believed Cummings should resign, contradicting claims that the scandal had been artificially concocted by disgruntled Remainers as revenge on the man they believed manipulated the referendum result. As the scandal deepened, 44 Tory MPs called for Cummings to resign or be sacked (Mason 2020c).

Johnson's approval ratings plunged 20 percentage points in the four days following the revelations to their lowest levels ever (from 19\% to 1\%), and government approval dropped 16 percentage points (from 14\% to $2 \%$ ) in a single day (Savanta 2020). Once again, an explanation for this precipitous fall in legitimacy can be found in word and deed failing to align. The high mimetic narrativization of events, in which the 'stay home' message was communicated not as 'a request', but as an emergency 'instruction' (BBC 2020e), was suddenly being presented as open to interpretation. The government appeared to be saying that if one's motives were high enough, one could flout the rules, the importance of which they had spent weeks establishing. For public performance to be effective, narratives need to be acted out in accordance with the 'genre constraints' described above, since 'no matter how intrinsically effective [they are], collective representations do not speak themselves' (Alexander 2004, p. 530). Government actions had failed to conform with the genre under which they were narrativizing the crisis, revealing a de-fused performance that wreaked havoc on the coherence of their drama. 


\section{Conclusion}

Drawing upon a range of tools for cultural analysis-including narrativization and its link to genre, ritual process and social drama, casting and interpellation, scripting and performance-this paper has tried to specify the ways in which shifts in meaning-making resulted in changes in the political fortune of powerful actors, alterations in public behaviour, and ultimately in life and death outcomes for tens of thousands of UK citizens. It has mapped out specific turning points at which cultural changes in the management of the crisis can be shown to have had often dire impacts on health outcomes. In other words, it has tried to demonstrate why meaning-making matters, and why sociologists ought to pay attention to it. Precisely because these mechanisms of sense-making can be shown to impact spheres of social life beyond the cultural, their functioning should be of interest not only to cultural analysts, but also to those concerned with public health and administration more broadly. The lesson, in other words, is that viral threats cannot be treated merely from a medical science perspective of the most technically efficacious ways to halt the spread of a disease, or even from a narrowly political perspective of how to represent, govern, legislate, and manage an organised polity in the midst of an outbreak. Nor should we stop short at the important point of underlying the social origins of COVID-19 (Horton 2020). Cultural processes should also be recognised as lying at the heart of both public health and statecraft, since culture composes the media through which these other practices are necessarily transacted.

As well as demonstrating culture's relative autonomy and offering an empirical illustration of the potential of the Strong Program in cultural analysis, this paper has also made a series of other contributions to cultural sociology. For instance, in showing the effects of casting the virus as a sometimes more, sometimes less, threatening antagonist, it has demonstrated how social performance theory needs to take more seriously the way in which non-human actors become inducted into social dramas. By analysing the ritual behaviour that took place around the sacralised NHS, it has shown ritual's role in rendering social conflicts and divisions to public audiences, as much as its more familiar role in affirming consensus and social cohesion. In showing how metaphor simplified a complex reality, redefined the form and gravity of the crisis, and reshaped the meaning of healthcare workers' deaths so as to shift responsibility away from the government, it has revealed mechanisms through which culture (in the form of figurative expression) is able to directly impinge on political process. In showing how flattery can operate as a kind of hailing, it has shown how expressions of praise and gratitude can function as a mode of interpellative power, similarly capable of shifting responsibilities. Finally, in charting the progression of the crisis through the stages of a secular ritual process, it has not only shown how anthropological theories of ritual can be productively interwoven with literary theories of narrative to provide hermeneutic forms of explanation, but has also shed light on the meaning work that lies behind how crises are triggered, how they are elevated to dramatic heights, and how they are lowered back down again.

Though the focus here has been on the diachronic evolution of a single case, future research in this vein would benefit from taking a comparative multi-case 
approach. This would enable tracing the impact of meaning-making processes synchronically across national contexts, showing how differences in governmental sense-making shaped divergent public health policies in ways that resulted in differences in behaviour, and infection and death rates. Studying the C19 pandemic in this way is particularly promising for the further demonstration of culture's relative autonomy in that unlike in many other cases of sociological interest, one of the key variables to be monitored is the behaviour of an indifferent pathogen, rather than that of reflexive human beings, capable of their own internalising, interpreting, and performing processes. This ability to bypass what Giddens (1987) called the 'double hermeneutic', in other words, bolsters the possibility of specifying more direct mechanisms of the causal impacts of culture.

Turner's fourfold schema of the passage of a social drama concludes with either 'reintegration', typically involving some change in the social structure into which that reintegration takes place, or else schismogenesis - the initiation of a permanent 'breach between contesting parties' (1980, p. 151). Reintegration might be said to have occurred if and when the virus has become an accepted part of everyday life in the UK and considered something like seasonal flu, perhaps through the development of more successful means of treating its symptoms, and the emergence of a shared consensus on reading it in low mimetic quotidian terms. Alternatively, a conclusion signalling schism might arise if and when the virus is somehow overcome and separated from the field of view as a present threat, perhaps through a successful vaccination programme leading to a critical mass of immunity within the population. Another event around which schism may arise is the ritual management of political sanction - through ballot or public enquiry-for the government's failure to shift from a low mimetic to a tragic narrativization of events early enough and maintain its coherent projection in both rhetoric and action for long enough, or in response to some mismanaged future second wave. A complete manifestation of any these outcomes is clearly not yet present, though aspects of all remain latent and virtual possibilities.

Another conclusive possibility is also worth noting. Turner emphasises that 'during attempts to redress conflict', '[n]ew norms and rules may have been generated... old rules will have fallen into disrepute and have been abrogated' (1974, p. 42). If this social drama follows the pattern of many others before it, the social disruption brought about by the anti-structural lockdown period of redress may lead to a makeover of social relations. Though lockdown experiences have been highly variable, a recent poll revealed that only $9 \%$ of the UK public want things to return to normal after lockdown ends (YouGov 2020a). Sanguine voices have speculated that the war metaphors that gave figurative expression to the height of the redressive period might be mobilised towards demands for a more egalitarian social dispensation in the UK, such as occurred following WWII (Bakewell 2020). Turner saw the interim liminal or liminoid periods in social life as a wellspring of social transformation, since members are granted the exceptional ability to stand aside from rule-bound social roles and both reflect upon and actively involve themselves in, alternative social arrangements. During such periods, settled standards of behaviour and order are subject to criticism and imaginative reinterpretation. Frequently enough, Turner wrote, '[y]esterday's liminal becomes today's stabilized, today's peripheral becomes 
tomorrow's centred' (1974, p. 16). Given the radical contingency of events, making any confident predictions about the content of possible social changes resulting from the UK's C19 social drama remains foolhardy, but asserting the likelihood of change itself appears less so.

Acknowledgements Thank you to the AJCS editors and anonymous reviewers for their generous comments on earlier drafts of this article, and to Anne Marie Champagne for all her help in the production of this article.

\section{References}

Alexander, J.C. 2004. Cultural Pragmatics: Social Performance between Ritual and Strategy. Sociological Theory 22 (4): 527-573.

Alexander, J.C. 2006. The Civil Sphere. Oxford University Press.

Alexander, J.C. 2011. Performative Revolution in Egypt: An Essay in Cultural Power. London: Bloomsbury Academic.

Alexander, J.C. 2012. Trauma: A Social Theory. Cambridge: Polity Press.

Alexander, J. C., \& P. Smith. (2003). The Strong Progam in Cultural Sociology: Elements of Structural Hermeneutics, in The Meanings of Social Life: A Cultural Sociology, Alexander, J. C. editor. Oxford: Oxford University Press.

Aljayyoussi, G. \& K. Cross. (2020, August 30) Revealed: How, on every measure, Britain's response to the Covid pandemic has been woeful. The Telegraph.

Althusser, L. 2014. On the Reproduction of Capitalism: Ideology and Ideological State Apparatuses. New York: Verso Books.

Anderson, P. (1964). Origins of the Present Crisis. New Left Review, 1(23).

Aristotle. 1996. Poetics. London: Penguin Classics.

Bakewell, J. (2020, May 8). VE Day was the spark for change. Coronavirus could be too. The Guardian.

Bakhtin, M. 1986. Speech Genres and Other Late Essays. Austin: University of Texas Press.

Barthes, R. 1977. Introduction to the Structural Analysis of Narratives. In Image Music Text, ed. R. Barthes, 79-124. London: Fontana Press.

Bartlett, N. (2019, December 2). Boris Johnson urges break up of 'top-down monopolistic' NHS in 2002 speech. Mirror.

Baudrillard, J. 2002. The Spirit of Terrorism. London: Verso Books.

Bauman, Z. 1989. Modernity and the Holocaust. New York: Wiley.

BBC. (2020a, April 27). Minute's silence for fallen key workers. BBC News. https://www.bbc.com/news/ uk-politics-52445867

BBC. (2020b, May 17). Dozens flout lockdown rules for park 'rave'. BBC News. https://www.bbc.com/ news/uk-england-shropshire-52696720

BBC. (2020c, April 28). UK failed to stockpile crucial protective kit. BBC News. https://www.bbc.com/ news/newsbeat-52440641

BBC. (2020d, April 21). Government 'has 8,000 offers from PPE suppliers'. BBC News. https://www.bbc. com/news/uk-politics-52369223

BBC. (2020e, April 3). Staying at home this weekend 'not a request'. BBC News. https://www.bbc.com/ news/uk-52155430

BBC. (2020f, March 13). More universities halt teaching and exams. BBC News. https://www.bbc.com/ news/education-51880355

Blackall, M. (2020, April 23). The volunteers making PPE on the homefront for UK health workers. The Guardian.

Blanchard, J. (2020, March 17). POLITICO London Playbook: The age of corona-Rishi leads the fightback-Commons rule change. POLITICO.

Bland, A. (2020, May 24). Dominic Cummings timeline: What we know about his movements. The Guardian. 
Boffey, D., \& R. Booth. (2020, April 13). UK missed three chances to join EU scheme to bulk-buy PPE. The Guardian.

Boltanski, C. 1999. Distant Suffering: Morality. Media and Politics: Cambridge University Press.

Booth, R. (2020, April 29). NHS staff coronavirus inquests told not to look at PPE shortages. The Guardian.

Boseley, S. (2020a, March 17). 'There is a policy of surrender': Doctor on UK's COVID-19 failures. The Guardian.

Boseley, S. (2020b, March 29). COVID-19 spreading too fast to lift lockdown in England-Sage advisers. The Guardian.

Bruner, J. 1990. Acts of Meaning. Cambridge MA: Harvard University Press.

Burke, K. 1966. Language As Symbolic Action: Essays on Life, Literature, and Method. Berkeley: University of California Press.

Bush, S. (2020, May 11). The government's "Stay Alert" slogan is working too hard. New Statesman.

Cabinet Office. (2008). National Risk Register.

Cabinet Office. (2017). National Risk Register of Civil Emergencies. Cabinet Office.

Calvert, J, G. Arbuthnott. \& J. Leake. (2020, April 19). Coronavirus: 38 days when Britain sleepwalked into disaster The Sunday Times. https://archive.vn/VLdAs

Calvert, J., G. Arbuthnott, J. Leake. \& D. Gadher. (2020, May 24). 22 days of dither and delay on coronavirus that cost thousands of British lives. The Sunday Times.

Campbell, D., M. Weaver. \& I. Sample. (2020, May 11). Top experts not asked to approve 'stay alert' coronavirus message. The Guardian.

Camus, A. (2002). The Plague. Penguin.

Cornford, F. (1914). The Origins of Attic Comedy. London: Edward Arnold.

Carrell, S., D. Pegg, F. Lawrence, P. Lewis, R. Evans, D. Conn, H. Davies. \& K. Proctor. (2020, April 24). Revealed: Dominic Cummings on secret scientific advisory group for COVID-19. The Guardian.

Clarke, P. (2020, March 6). Canary Wharf bankers are 'sleepwalking' into coronavirus crisis. Financial News.

Cockroft, S. (2020, March 14). UK's 'herd immunity' approach to tackling coronavirus questioned by World Health Organisation. London Evening Standard.

Cohen, N. (2020, May 2). The British charlatan style has been sent packing by too much reality I Nick Cohen. The Guardian.

Cohen, S. 1972. Folk Devils and Moral Panics: The Creation of the Mods and Rockers. London: Routledge.

Cohen, S. 2000. States of Denial: Knowing About Atrocities and Suffering. Cambridge: Polity Press.

Conn, D., F. Lawrence, P. Lewis, S. Carrell, D. Pegg, H. Davies, \& R. Evans. (2020, April 29). Revealed: The inside story of the UK's COVID-19 crisis. The Guardian.

Costello, A. (2020, April 27). The government's secret science group has a shocking lack of expertise. The Guardian.

Crace, J. (2020, March 3). Boris fails to convince with sanitised take on coronavirus. The Guardian.

Crawford, R., A. Davenport, R. Joyce, and P. Levell. 2020. Household spending and coronavirus. London: Institute For Fiscal Studies IFS.

Crerar, P., \& J. Armstrong. (2020, May 22). Dominic Cummings investigated by police after breaking COVID-19 lockdown rules. The Mirror.

Davies, H., D. Pegg. \& F. Lawrence. (2020, April 12). Revealed: Value of UK pandemic stockpile fell by $40 \%$ in six years. The Guardian.

Davis, J.E. 2002. Stories of Change: Narrative and Social Movements. Albany: State University of New York Press.

Davis, M., \& D. Lohm. (n.d.). Pandemics, Publics, and Narrative, in Pandemics, Publics, and Narrative, D. Lohm editor. Oxford: Oxford University Press.

DHSC. (2020, April 19). Response to Sunday Times Insight article-Department of Health and Social Care Media Centre.

Dilthey, W. (1972 [1900]) The Rise of Hermeneutics. New Literary History. Winter, 1972, 3(2): 229-244

Dilthey, W. 2002. The Formation of the Historical World in the Human Sciences. Oxford \& Princeton: Princeton University Press.

Dispatches. (2020, May 3). Coronavirus Did the Government Get It Wrong? In Channel 4. https://www. channel4.com/programmes/coronavirus-did-the-government-get-it-wrong

Dunn, T.N. \& M. Dathan. (2020, April 9). Bounding Back: Boris Johnson 'sitting up in bed' and improving as he fights coronavirus in intensive care. The Sun. 
Durkheim, E. 1995. The Elementary Forms of the Religious Life. Crows Nest: George Allen \& Unwin, Ltd.

Easton, M. (2020, March 11). Care home residents could be 'cocooned' over virus. BBC News. https:// www.bbc.com/news/uk-51828000

ECDC. (2020). Personal protective equipment (PPE) needs in healthcare settings for the care of patients with suspected or confirmed novel coronavirus (2019-nCoV).

England Rugby. (2020, March 7). Available at https://twitter.com/EnglandRugby/status/1236330340 320456705.

Erikson, K. 1966. Wayward Puritans: A Study in the Sociology of Deviance. New York: Wiley.

Evans, A. (2020, March 27). Question Time: Medical expert Richard Horton says UK 'wasted February' when it should have been preparing NHS for coronavirus cases. $i$ News.

Farnell, L.R. 1921. Greek Hero Cults and Ideas of Immortality. Oxford: Clarendon Press.

Ferguson, N. M., D. Laydon, G. Nedjati-Gilani, N. Imai, K. Ainslie, M. Baguelin, S. Bhatia, A. Boonyasiri, Z. Cucunubá, G. Cuomo-Dannenburg, A. Dighe, H. Fu, K. Gaythorpe, H. Thompson, R. Verity, E. Volz, H. Wang, Y. Wang, P. G. Walker, ... A. C. Ghani. (2020). Report 9: Impact of nonpharmaceutical interventions (NPIs) to reduce COVID-19 mortality and healthcare demand. 20.

Financial Times. (2020, March 14). UK cases top 1,100 as WHO questions virus approach. https://www. ft.com/content/b88f2c8e-660a-11ea-a3c9-1fe6fedcca75

Freedman, L. (2020). The real reason the UK government pursued "herd immunity"-and why it was abandoned. New Statesman.

Freud, S. 1917. Mourning and Melancholia. In Standard Edition of the Complete Psychological Works, ed. S. Freud. London: Hogarth Press.

Frye, N. (1957). Anatomy of Criticism: Four Essays. Princeton University Press.

Gallagher, P. (2019, November 28). Number of GPs has fallen while nursing vacancies hit 43,000 amid NHS crisis. The Independent.

Geertz, C. 1977. The Interpretation of Cultures. New York: Basic Books.

Ghosh, P. (2020, March 14). Some scientists say UK virus strategy 'risks lives'. BBC News. https://www. bbc.com/news/science-environment-51892402

Giddens, A. 1987. Social Theory and Modern Sociology. Cambridge: Polity Press.

Giles, C. (2020, April 22). UK coronavirus deaths more than double official figure, according to FT study. Financial Times.

Gilroy, P. (2005). After empire: Melancholia or convivial culture? Abingdon: Routledge.

Goffman, E. 1959. The Presentation of Self in Everyday Life. London: Penguin Books.

Goffman, E. (1974). Frame Analysis: An Essay on the Organization of Experience. Northeastern University Press.

Goorwich, S. (2020, May 7). People can't help flouting lockdown laws-But why? Metro.

gov.uk. (2020a). Secretary of State makes new regulations on coronavirus. Gov.Uk. https://www.gov.uk/ government/news/secretary-of-state-makes-new-regulations-on-coronavirus

gov.uk. (2020b). COVID-19: Government announces moving out of contain phase and into delay. GOV. UK. https://www.gov.uk/government/news/covid-19-government-announces-moving-out-of-conta in-phase-and-into-delay

gov.uk. (2020c). High consequence infectious diseases (HCID). GOV.UK. https://www.gov.uk/guidance/ high-consequence-infectious-diseases-hcid

gov.uk. (2020d). PM address to the nation on coronavirus: 10 May 2020. GOV.UK. https://www.gov.uk/ government/speeches/pm-address-to-the-nation-on-coronavirus-10-may-2020

gov.uk. (2020e). PM speech in Greenwich: 3 February 2020. GOV.UK. https://www.gov.uk/government/ speeches/pm-speech-in-greenwich-3-february-2020

Grieirson, J. (2020, May 5). UK government under fire after 'big influx' of COVID-19 cases from Europe revealed. The Guardian.

Griswold, W. 1987. The Fabrication of Meaning: Literary Interpretation in the United States, Great Britain, and the West Indies. American Journal of Sociology 92 (5): 1077-1117.

Guardian Letters. (2020, May 26). Testing questions on the drive to Barnard Castle I Letters. The Guardian.

Habermas, J. 1988. Legitimation Crisis. Cambridge: Polity Press.

Hancock, M. (2020a, January 27). Wuhan coronavirus: Health Secretary's statement to Parliament. gov. uk

Hancock, M. (2020b, March 14). We must all do everything in our power to protect lives. The Telegraph. 
Harding, L., R. Mason, D. Sabbagh, M. Busby, D. Campbell. \& O. Bowcott. (2020, April 17). Boris Johnson and coronavirus: The inside story of his illness. The Guardian.

Helm, T. (2020, March 14). Only 36\% of Britons trust Boris Johnson on coronavirus, poll finds. The Observer.

Hickman, A. (2020, May 12). PR pros lambast new Government 'Stay alert' slogan as 'unclear' and 'unhelpful'. PR Week.

Higham, A. (2020, April 13). Lockdown breach: How to report people ignoring lockdown rules. The Express.

Hope, C., \& H. Dixon. (2020, May 1). The story behind 'Stay Home, Protect the NHS, Save Lives'-The slogan that was 'too successful'. The Telegraph.

Horton, R. (2020). Comment: COVID-19 is not a pandemic. The Lancet. Vol 396. September 26.

Hume, D. (1985). A Treatise of Human Nature: Being an Attempt to Introduce the Experimental Method of Reasoning into Moral Subjects. Penguin Classics.

Hunter, D. (2020, April 1). Coronavirus: If we are in a war against COVID-19 then we need to know where the enemy is. The Conversation.

Hussain, D. (2020, May 26). Tory voters say Dominic Cummings should resign over 'lockdown breach'. Daily Mail.

ITV. (2020, April 8). 15-year-old uses 3D printer to make masks for frontline NHS workers I MeridianITV News.

Jacobs, R.N. 1996. Civil Society and Crisis: Culture, Discourse, and the Rodney King Beating. American Journal of Sociology 101 (5): 1238-1272.

Jacobs, R. N., \& P. Smith. (1997). Romance, Irony, and Solidarity. Sociological Theory 15 (1): 60-80.

Johnson, B. (2020, May 10). PM address to the nation on coronavirus: 10 May 2020. GOV.UK. https:// www.gov.uk/government/speeches/pm-address-to-the-nation-on-coronavirus-10-may-2020

Johnstone, K. 1981. Impro: Improvisation and the Theatre. London: Routledge.

Keen, D. 2006. Endless War? Hidden Functions of the 'War on Terror'. London: Pluto Press.

Kucharski, A. (2020, May 24). Available at https://twitter.com/AdamJKucharski/status/1264650504 388427783.

Laclau, E. (1996). Why do empty signifiers matter to politics? In Emancipation(s) (pp. 36-46). London: Verso.

Lamont, M., and V. Molnár. 2002. The Study of Boundaries in the Social Sciences. Annual Review of Sociology 28: 167-195.

Latour, B. 1996. On actor-network theory: A few clarifications. Soziale Welt 47 (4): 369-381.

Lay, K., \& O. Wright. (2020, April 11). Coronavirus: Only use the PPE you need, Hancock tells healthcare workers. The Times.

Liu, A. (2020, April 10). Blaming China for coronavirus isn't just dangerous. It misses the point. The Guardian.

Lovett, S. (2020, May 11). 390,000 sign petition demanding parents given choice to keep children at home. The Independent.

Lukács, G. 1971. The Theory of the Novel: A Historico-philosophical Essay on the Forms of Great Epic Literature. Cambridge: MIT Press.

MacInnes, P. (2020, March 13). Premier League, Football League and WSL suspended until April. The Guardian.

Malik, N. (2020, March 30). In this crisis, the Tory cuts can no longer be hidden by empty gestures. The Guardian.

Mason, R. (2020a, March 23). Hancock accuses those still socialising in UK of being 'very selfish'. The Guardian.

Mason, R. (2020b, June 7). UK failure to lock down earlier cost many lives, top scientist says. The Guardian.

Mason, R. (2020c, May 27). Tory anger at Dominic Cummings grows as 61 MPs defy Boris Johnson. The Guardian.

Mason, R. (2020d, May 5). Boris Johnson boasted of shaking hands on day Sage warned not to. The Guardian.

Mason, R., \& L. O'Carroll. (2020, March 26). No 10 accused of putting 'Brexit over breathing' in COVID-19 ventilator row. The Guardian.

Mast, J. 2013. The Performative Presidency: Crisis and Resurrection During the Clinton Years. New York: Cambridge University Press. 
Mathers, M. (2020, May 18). Coronavirus Belgium: 'Outraged' medics turn their backs in protest at PM's handling of pandemic. The Independent.

Mbembe, A. 2003. Necropolitics. Public Culture. 15 (1): 11-40.

McKinstry, L. (2011, Nov 28). No surrender to these greedy and selfish strikers. The Express.

Mendick, R. (2020, May 18). The Government's mixed messages mean British workers do not know whether to stay or go. The Telegraph.

Menendez, E. (2020, March 3). Up to $80 \%$ of people in UK could catch coronavirus in worst-case scenario. Metro.

Merrick, R. (2020, May 19). Scientists to blame if government made coronavirus mistakes, cabinet minister says. The Independent.

Meyer, D.S., and N. Whittier. 1994. Social Movement Spillover. Social Problems 41 (2): 277-298.

Morgan, M. 2016. Pragmatic Humanism: On the Nature and Value of Sociological Knowledge. Abingdon, Oxon \& New York: Routledge.

Morgan, M. 2018. Performance and Power in Social Movements: Biko's role as a Witness in the SASO/ BPC Trial. Cultural Sociology. 12 (4): 456-477.

Morgan, M. 2020. Movement intellectuals engaging the grassroots: A strategy perspective on the Black Consciousness Movement. The Sociological Review 8 (5): 1124-1142.

Morgan, M., and P. Baert. 2015. Conflict in the Academy: A Study in the Sociology of Intellectuals. London: Palgrave Macmillan.

Murphy, N. (2020, March 16). Coronavirus: Concerned parents vow to keep kids off school with COVID-19 walkout. https://www.mirror.co.uk/news/uk-news/coronavirus-concerned-parents-vowkeep-21698968

Nairn, T. (1964). The British Political Elite. New Left Review, 1(23).

Nerlich, B. (2020, March 17). Metaphors in the time of coronavirus. Making Science Public. https://blogs .nottingham.ac.uk/makingsciencepublic/2020/03/17/metaphors-in-the-time-of-coronavirus/

Newsnight. (2020, March 13). Coronavirus: Can herd immunity protect the population? - BBC Newsnight. https://www.youtube.com/watch? v=blkDulsgh3Q

Ng, K. (2020, March 5). Philip Schofield tries to avoid shaking Boris Johnson's hand, but PM does it anyway. The Independent.

Nuki, P. (2020, April 28). Revealed: The three UK sporting events that may have led to a coronavirus death spike. The Telegraph.

Nuki, P., \& B. Gardner. (2020, March 28). Exercise Cygnus uncovered: The pandemic warnings buried by the government. The Telegraph.

Olsen, K.A. 2014. Telling Our Stories: Narrative and Framing in the Movement for Same-Sex Marriage. Social Movement Studies 13 (2): 248-266.

Open Letter. (2020a, March 14). Open letter to the UK Government regarding COVID-19. https://sites .google.com/view/covidopenletter/home

Open Letter. (2020b, March 14). Public request to take stronger measures of social distancing across the UK with immediate effect. https://maths.qmul.ac.uk/ vnicosia/UK_scientists_statement_on_coron avirus_measures.pdf

Opinium. (2020a, May 16). Public opinion on coronavirus - 13th May. Opinium. https://www.opini um.co.uk/public-opinion-on-coronavirus-13th-may/

Opinium. (2020b, May 21). The Political Report, 21st May. Opinium. https://www.opinium.co.uk/wpcontent/uploads/2020/05/Opinium-Political-Report-21st-May-2020.pdf

Osborne, S. (2020, May 21). Police wake up caravan tourists flouting lockdown rules in Newquay. The Independent.

Pache, C. O. (2009). The hero beyond himself: Heroic death in ancient Greek poetry and art. In S. Albersmeier (Ed.), Heroes: Mortals and Myths in Ancient Greece (Walters Art Museum, pp. 88-107).

Panorama. (2020, April 27). Panorama-Has the Government Failed the NHS? BBC.

Pareek, M., M.N. Bangash, N. Pareek, D. Pan, S. Sze, J.S. Minhas, W. Hanif, and K. Khunti. 2020. Ethnicity and COVID-19: An urgent public health research priority. The Lancet 395 (10234): 1421-1422.

Payne, S., \& C. Cookson. (2020, May 5). Boris Johnson shook hands 'continuously' despite science panel warnings.Financial Times.

Plummer, K. 2019. Narrative Power: The Struggle for Human Value. Cambridge: Polity Press.

Polletta, F. 2006. It Was Like a Fever: Storytelling in Protest and Politics. Chicago: University of Chicago Press.

Popper, K. 1963. Conjectures and refutations: The growth of scientific knowledge. London: Routledge. 
Proctor, K. (2020, April 20). Liverpool v Atlético virus links 'interesting hypothesis', says government scientist. The Guardian.

Radcliffe-Brown, A. R. (1965). Structure and Function in Primitive Society. Free Press.

Rawlinson, K., M. Weaver, A. Mohdin, A. Rourke, M. Weaver, L. Kuo, A. Giuffrida, L. Kuo. \& M. Weaver. (2020, February 24). WHO plays down pandemic fears after seventh person dies in Italyas it happened. The Guardian.

Rayner, G., C. Tominey, A. Mikhailova, \& C. Hymas. (2020, April 17). Cabinet ministers admit there is no lockdown exit plan as they wait for Boris Johnson's return. The Telegraph.

Reuters. (2020, January 24). Coronavirus risk to British public remains low: Health minister. Reuters. https://www.reuters.com/article/us-china-th-britain-hancock-idUSKBN1ZN1R9

Ricoeur, P. 2016. The Narrative Function. In Hermeneutics and the Human Sciences: Essays on Language, Action and Interpretation, Reprinted ed, ed. J.B. Thompson, 236-258. Cambridge: Cambridge University Press.

Rosenberg, C.E. 1989. What Is an Epidemic? AIDS in Historical Perspective. Daedalus 118 (2): 1-17.

Rosenberg, C.E. 1992. Explaining Epidemics. Cambridge: Cambridge University Press.

Roy, A. (2003). War Talk. Boston: South End Press.

Sabbagh, D., S. Morris. \& C. Cook. (2020, April 21). Experts call for inquiry into local death toll after Cheltenham Festival. The Guardian.

Salmon, C. 2017. Storytelling: Bewitching the Modern Mind. London: Verso.

Savanta. (2020). Coronavirus Data Trackers. Savanta. https://savanta.com/coronavirus-data-tracker/

Schechner, R. (1988). Performance Theory. London: Routledge.

Sheridan, D. (2020, May 10). Chaos over Government's 'stay alert' slogan as Scotland, Wales and Northern Ireland reject it. The Telegraph.

Shipman, T., \& C. Wheeler. (2020). Coronavirus: Ten days that shook Britain-and changed the nation for ever. The Sunday Times.

Stewart, H. \& I. Sample (2020, 11th June). Coronavirus: enforcing UK lockdown one week earlier 'could have saved 20,000 lives'. The Guardian.

Sky News. (2020, March 13). Coronavirus: 'I speak scientific truth to power' says chief scientific adviser for England. Sky News. https://news.sky.com/video/coronavirus-i-speak-scientific-truth-to-power -says-chief-scientific-adviser-for-england-11956851

Smith, P. 2005. Why War?: The Cultural Logic of Iraq, the Gulf War, and Suez. Chicago: Chicago University Press.

Sontag, S. (1978, February 23). Disease as Political Metaphor. New York Review of Books.

SPI-B. (2020). SPI-B return to SAGE on the use of behavioural and social interventions on a COVID-19 epidemic in the UK (3 March 2020).

SPI-M-O. (2020). SPI-M-O: Consensus Statement on 2019 Novel Coronavirus (COVID-19). https:// assets.publishing.service.gov.uk/government/uploads/system/uploads/attachment_data/file/87371 3/01-spi-m-o-consensus-statement-on-2019-novel-coronavirus-_covid-19_.pdf

Staton, B., L. Hughes, N. Asgari, \& A. Barker. (2020, April 1). Why the NHS is struggling to protect staff from coronavirus. Financial Times.

Stewart, H., \& M. Busby. (2020, March 13). Coronavirus: Science chief defends UK plan from criticism. The Guardian.

Stewart, H., \& D. Campbell. (2020, April 10). NHS workers angered at Hancock's warning not to overuse PPE. The Guardian.

Stewart, H., K. Proctor. \& H. Siddique. (2020, March 12). Johnson: Many more people will lose loved ones to coronavirus. The Guardian.

Stewart, H., \& M. Weaver. (2020, May 23). Grant Shapps backs Dominic Cummings over lockdown breach. The Guardian.

Swidler, A. 1986. Culture in Action: Symbols and Strategies. American Sociological Review 51 (2): 273-286.

Taylor, C. 1971. Interpretation and the Sciences of Man. The Review of Metaphysics 25 (1): 3-51.

The Mirror. (2020, April 11). 'If you flout the coronavirus lockdown you're a traitor to the national cause'. The Mirror.

This Morning. (2020, March 5). Boris Johnson on Priti Patel, Coronavirus and Changing Nappies. https $: / /$ www.youtube.com/watch?v=vOHiaPwtG14\&feature=youtu.be

Thompson, E. P. (1965). The Peculiarities of the English. Socialist Register, 311-362.

Thompson, E.P. 1978. Poverty of Theory: An Orrery of Errors. London: Merlin Press. 
Tolhurst, A. (2020, May 17). Confidence in Government's handling of coronavirus crisis drops amid confusion over 'stay alert' slogan.

Tsilipakos, L. 2020. Descriptive Accuracy in History: The Case of Narrative Explanations. Philosophy of Social Science. 50 (4): 283-312.

Tucker, M., \& A. Goldberg. (2020, May 26). Sports events 'shut down too late to save lives'. BBC News.

Turner, V. 1969. The Ritual Process: Structure and Anti-Structure. Chicago: Aldine Publishing Company.

Turner, V. 1974. Dramas, Fields, and Metaphors: Symbolic Action in Human Society. Ithaca: Cornell University Press.

Turner, V. 1980. Social Dramas and Stories about Them. Critical Inquiry 7 (1): 141-168.

Turner, V. 1988. The Anthropology of Performance. New York: PAJ Publications.

Vallance, P. (2020, March 13). Coronavirus: 'I speak scientific truth to power' says chief scientific adviser for England. Sky News.

van Gennep, A. (2004). The Rites of Passage. London: Routledge.

Wagner-Pacifici, R. 1986. The Moro Morality Play: Terrorism as Social Drama. Chicago: University of Chicago Press.

Wagner-Pacifici, R., and B. Schwartz. 1991. The Vietnam Veterans Memorial: Commemorating a Difficult Past. American Journal of Sociology 97 (2): 376-420.

Wakefield, M. (2020, April 25). Getting coronavirus does not bring clarity I The Spectator. The Spectator.

Wald, P. 2008. Contagious: Cultures, Carriers, and the Outbreak Narrative. Durham: Duke University Press.

Walker, A. (2020, May 10). 'Alert for what?': Manchester confused by new government slogan. The Guardian.

Walker, P. (2020a, April 19). Boris Johnson missed five coronavirus Cobra meetings, Michael Gove says. The Guardian.

Walker, P. (2020b, May 11). Coronavirus lockdown: What are the new rules announced by Boris Johnson? The Guardian.

Weale, S., P. Walker, \& J. Halliday. (2020, May 19). No 10 retreats as rebellion over schools gathers pace. The Guardian.

Weaver, M. (2020, May 22). Pressure on Dominic Cummings to quit over lockdown breach. The Guardian.

Weaver, M., \& V. Dodd. (2020, May 24). Dominic Cummings facing possible police investigation as pressure mounts. The Guardian.

Whately, H. (2020) Tweet: https://twitter.com/Helen_Whately/status/1253403188360855554?s=20. Twitter.

White, G. 2013. Audience Participation in Theatre: Aesthetics of the Invitation. Basingstoke: Palgrave Macmillan.

Whitty, C. (n.d.). CMO for England statement on the Wuhan novel coronavirus. GOV.UK. Retrieved 18 May 2020, from https://www.gov.uk/government/news/cmo-for-england-statement-on-the-wuhan -novel-coronavirus

WHO. (2020a, January 31). 2019-nCoV outbreak is an emergency of international concern. World Health Organization.

WHO. (2020b, March 11). WHO Director-General's opening remarks at the media briefing on COVID-19.

Williams, R. 1977. Marxism and Literature. Oxford: Oxford University Press.

Winch, P. 1958. The Idea of a Social Science and its Relation to Philosophy. London: Routledge.

Wood, V. (2020, April 16). Coronavirus: Matt Hancock ridiculed after announcing badge to support care sector workers. The Independent.

Wooding, D. (2020, April 4). Boris Johnson says fear of never seeing his new son gave him strength to beat coronavirus. The Sun.

Woods, Ju. (2020, April 16). The care home crisis won't be solved by handing out some badges. The Telegraph.

YouGov. (2020a). Perception of government handling of COVID-19| YouGov. https://yougov.co.uk/topic s/international/articles-reports/2020/03/17/perception-government-handling-covid-19

YouGov. (2020, May 11). Brits split on changes to coronavirus lockdown measures I YouGov. https:// yougov.co.uk/topics/health/articles-reports/2020/05/11/brits-split-changes-coronavirus-lockdownmeasures 
Publisher's Note Springer Nature remains neutral with regard to jurisdictional claims in published maps and institutional affiliations.

Marcus Morgan is a cultural and political sociologist at the University of Bristol. His latest articles include 'A Cultural Sociology of Populism', International Journal of Politics, Culture and Society (2020), and 'Movement Intellectuals Engaging the Grassroots: A Strategy Perspective on the Black Consciousness Movement', Sociological Review (2020). He is also the author of Pragmatic Humanism (Routledge, 2016), and co-author, with Patrick Baert, of Conflict in the Academy: A Study in the Sociology of Intellectuals (Palgrave, 2015). 